\title{
Ornamental Exterior versus Therapeutic Interior of Madagascar Periwinkle (Catharanthus roseus): The Two Faces of a Versatile Herb
}

\author{
Naghmeh Nejat, ${ }^{1}$ Alireza Valdiani, ${ }^{2}$ David Cahill, ${ }^{3}$ Yee-How Tan, \\ Mahmood Maziah, ${ }^{1,2,5}$ and Rambod Abiri ${ }^{2}$ \\ ${ }^{1}$ Institute of Tropical Agriculture, Universiti Putra Malaysia (UPM), 43400 Serdang, Selangor DE, Malaysia \\ ${ }^{2}$ Department of Biochemistry, Faculty of Biotechnology and Biomolecular Sciences, Universiti Putra Malaysia (UPM), \\ 43400 Serdang, Selangor DE, Malaysia \\ ${ }^{3}$ School of Life and Environmental Sciences, Faculty of Science Engineering \& Built Environment, Deakin University, \\ Melbourne, VIC 3220, Australia \\ ${ }^{4}$ Department of Plant Protection, Faculty of Agriculture, Universiti Putra Malaysia (UPM), 43400 Serdang, Selangor DE, Malaysia \\ ${ }^{5}$ Institute of Bioscience, Universiti Putra Malaysia (UPM), 43400 Serdang, Selangor DE, Malaysia
}

Correspondence should be addressed to Naghmeh Nejat; nanejat@gmail.com, Alireza Valdiani; alireza.valdiani@gmail.com, and Mahmood Maziah; maziahm@upm.edu.my

Received 3 July 2014; Accepted 29 September 2014

Academic Editor: Da C. Hao

Copyright (C) 2015 Naghmeh Nejat et al. This is an open access article distributed under the Creative Commons Attribution License, which permits unrestricted use, distribution, and reproduction in any medium, provided the original work is properly cited.

\begin{abstract}
Catharanthus roseus (L.) known as Madagascar periwinkle (MP) is a legendary medicinal plant mostly because of possessing two invaluable antitumor terpenoid indole alkaloids (TIAs), vincristine and vinblastine. The plant has also high aesthetic value as an evergreen ornamental that yields prolific blooms of splendid colors. The plant possesses yet another unique characteristic as an amiable experimental host for the maintenance of the smallest bacteria found on earth, the phytoplasmas and spiroplasmas, and serves as a model for their study. Botanical information with respect to synonyms, vernacular names, cultivars, floral morphology, and reproduction adds to understanding of the plant while the geography and ecology of periwinkle illustrate the organism's ubiquity. Good agronomic practices ensure generous propagation of healthy plants that serve as a source of bioactive compounds and multitudinous horticultural applications. The correlation between genetic diversity, variants, and TIA production exists. MP is afflicted with a whole range of diseases that have to be properly managed. The ethnobotanical significance of MP is exemplified by its international usage as a traditional remedy for abundant ailments and not only for cancer. TIAs are present only in micro quantities in the plant and are highly poisonous per se rendering a challenge for researchers to increase yield and reduce toxicity.
\end{abstract}

\section{Introduction}

The genus Catharanthus consists of eight species of which seven are endemic to Madagascar and one, C. pusillus, is endemic to India. Catharanthus roseus, Madagascar periwinkle (hereafter MP), is an important floral species in horticulture and is one of the few pharmacological plants that have a long history. It could be traced to Mesopotamian folklore going as far back as 2600 BCE. This plant still plays a considerable role today in herbal and traditional medicine for treatment of various diseases. The therapeutic properties were ascribed to a number of chemicals in the alkaloid class sometime in the mid-1950s $[1,2]$.

Medicinal plants have played a key role in world health care [3]. MP apart from being the most important source of natural drugs is also one of the premier model organisms to study plant alkaloid metabolites due to its ability to synthesize a wide range of terpenoid indole alkaloids (TIAs) with a broad pharmaceutical spectrum [4-7]. However, MP is potentially poisonous as are many plants of the dogbane family. Nowadays MP comes in many different varieties and colors ranging from white, hot pink, and mauve to the original pink as 
a result of breeding experiments. As previously published reviews on MP mostly concentrate on the pharmaceutical and chemical compounds of the herb, lack of information about the other features of the species is extremely tangible. The aim of this review is to provide insights into agrotechnological, biological, ecological, and medicinal aspects (particularly anticancer compounds) of MP as well as updated information on the new cultivars that have been introduced to the horticultural industry.

\section{Botany}

2.1. Taxonomic Classification. Inconsistency of nomenclature in the literature is due to changes made in plant taxonomic classification with continuous research [8]. In the appellation of Catharanthus roseus (L.) G. Don, Catharanthus means clean or pure flower in Greek, roseus signifies being rosecolored in Latin, L. is the standard abbreviation for Linnaeus, who first published the plant's description, and G. Don refers to George Don, who named the flower as such in 1837 [6].

Catharanthus roseus known as the Madagascar periwinkle (MP) was formerly classified as the species Vinca rosea L. (1759) (basionym or original name), Pervinca rosea (L.) Moench (1794), Lochnera rosea (L.) Rchb. ex Endl. (1838), and Ammocallis rosea (L.) Small (1903), which are homotypic synonyms [9]. Vinca guilelmi-waldemarii Klotzsch is recognized as a heterotypic synonym [10].

Below describes the classification of the Catharanthus roseus species.

Domain: Eukarya: eukaryotes.

Kingdom: Plantae: plants.

Subkingdom: Tracheobionta: vascular plants.

Superdivision: Spermatophyta: seed plants.

Division: Magnoliophyta: flowering plants.

Class: Magnoliopsida: dicotyledons.

Subclass: Asteridae.

Superorder: Gentiananae.

Order: Gentianales.

Family: Apocynaceae: dogbane.

Subfamily: Rauvolfioideae.

Tribe: Vinceae.

Genus: Catharanthus G. Don.

Specific epithet: roseus (Linnaeus) G. Don.

Botanical name: Catharanthus roseus (Linnaeus) G. Don (1837): Madagascar periwinkle [8, 11-13].

Vernacular names of the herb in various cultures and languages have been listed in Table 1.

2.2. Morphological Characteristics. MP is a perennial or annual evergreen, semishrub or herbaceous plant that grows up to one meter in height and secretes milky latex. The roots extend to $70 \mathrm{~cm}$ in depth. The leaves of the plant are elliptical
TABLE 1: Vernacular names of Madagascar periwinkle (Catharanthus roseus) in different languages*.

\begin{tabular}{|c|c|}
\hline Language & Common name \\
\hline Bengali & Nayantara \\
\hline Chinese & Chang Chun Hua \\
\hline Dutch & Roze maagdenpalm \\
\hline English & $\begin{array}{l}\text { Bright-eyes, Cape periwinkle, graveyard plant, } \\
\text { Madagascar periwinkle, old-maid, } \\
\text { old-maid-flower, rose periwinkle, rosy periwinkle }\end{array}$ \\
\hline Ethiopia & Phlox \\
\hline Creole & Bigalo \\
\hline French & $\begin{array}{l}\text { Pervenche de Madagascar, rose amère, sorcerer's } \\
\text { violet }\end{array}$ \\
\hline German & Zimmerimmergrün \\
\hline Creole & Kaka poule \\
\hline Hindi & Sadabahar, Baramassi, Ainskati, Ushamanjairi \\
\hline Indonesian & Tapak dara, kembang sari cina \\
\hline Konkani & Sadapushpa \\
\hline Malayalam & Nithyakalyani, Savakkottappacha, Ushamalari \\
\hline Malay & Kemunting cina \\
\hline Marathi & Sada-phul (Sadaphuli) \\
\hline Myanmarese & Thin-Baw-MA-Hnyo \\
\hline Persian & Gul-e-farang \\
\hline Portuguese & $\begin{array}{l}\text { Boa-noite, Boa-tarde, Lavadeira, Pervinca-rosa, } \\
\text { Vinca-de-gato, } \\
\text { Vinca-de-madagascar, Vina-rósea }\end{array}$ \\
\hline Punjabi & Rattanjot \\
\hline Sanskrit & Nityakalyani \\
\hline Krio & Ngyange \\
\hline Afrikaans & Kanniedood \\
\hline Spanish & $\begin{array}{l}\text { Chatas, Chula, Pervinca de Madagascar, Vinca } \\
\text { pervinca, Hierba doncella }\end{array}$ \\
\hline Swedish & Rosensköna \\
\hline Tamil & Sudukattu mallikai \\
\hline Telugu & Billaganneru \\
\hline
\end{tabular}

* References: $[9,17]$.

to oblong in shape, $2.5-9 \mathrm{~cm}$ long, $1-3.5 \mathrm{~cm}$ broad, glossy green above, and pale green below with a pale midrib and opposite in orientation. Petioles are green or red and $1-1.8 \mathrm{~cm}$ long. The inflorescence is racemose. Flowers are pentamerous, actinomorphic, and colored pink, rose-purple, blue, salmon, scarlet, or white with purple, red, pink, pale yellow, or white "eye" in the center and a mauve throat (Figures $1(\mathrm{a})-1(\mathrm{c}))$. The corolla tube is cylindrical, $2-3 \mathrm{~cm}$ long with five petal-like lobes. Stamens are inserted $0.4-0.6 \mathrm{~cm}$ below the corolla mouth, consisting of very short white colored filaments and filiform, subsessile anthers. Pistils range from 17 to $26 \mathrm{~mm}$ in length, made up of two narrow, long carpels consisting of a glabrous stigma, style, ovary, and 2-seriate 


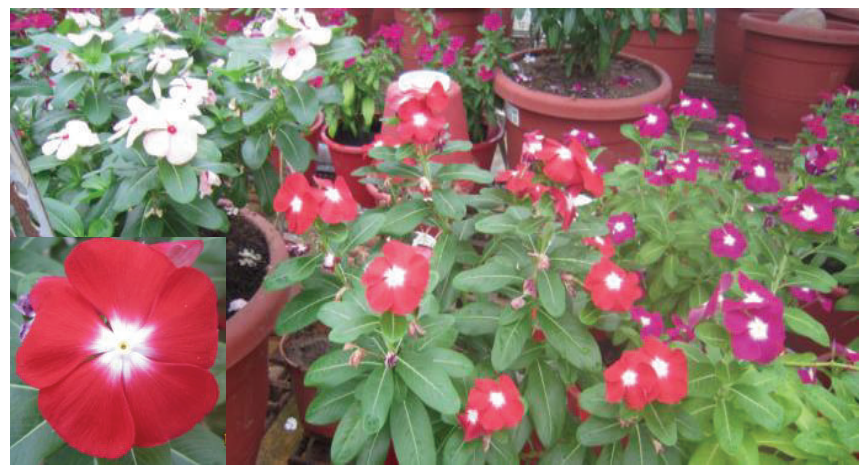

(a)

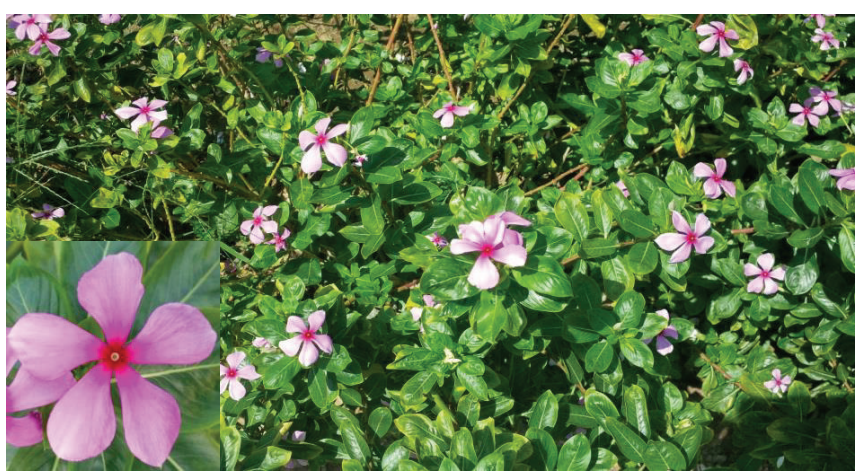

(b)

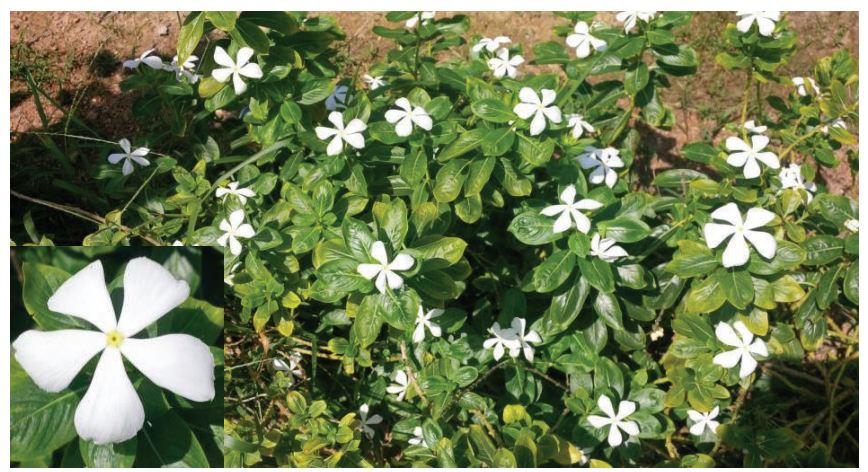

(c)

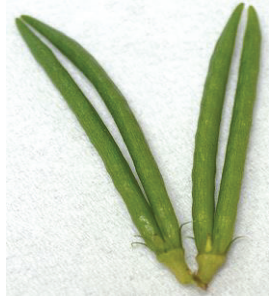

(d)

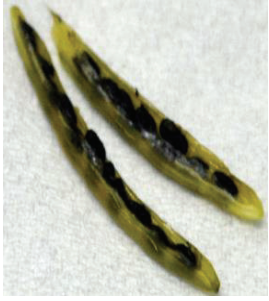

(e)

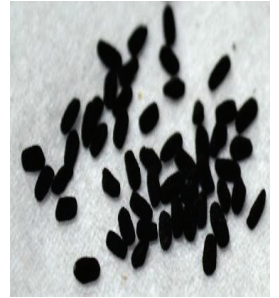

(f)

FIGURE 1: (a) Artificial hybrids of MP in flower stage; (b) wild types with purple flowers "rosea"; (c) wild types with white flowers "alba"; (d) fruits which are composed of two free narrow cylindrical follicles; (e) seeds inside the follicle; (f) seeds. All images represent the real sizes, approximately. The artificial hybrids are clearly differentiated from those wild types due to their floral architecture and petals structure which are wider, thicker, and more compressed than the wild ones. 
ovules. Each fruit is composed of two free, narrow cylindrical follicles, $2-4.5 \mathrm{~cm}$ long and $3 \mathrm{~mm}$ wide, which houses $10-$ 20 oblong, minute seeds, $2-3 \mathrm{~mm}$ in length (Figures $1(\mathrm{~d})-$ 1(f)). These seeds comprise black cotyledons which are flat and slightly shorter than the radical and a scanty endosperm $[9,14-16]$.

\section{Geographical Distribution and Ecology}

MP is a plant species native to Western Indian Ocean's large island of Madagascar next to Africa. It has been introduced as a popular ornamental plant in many tropical and subtropical regions worldwide. This herb is widely cultivated commercially in Spain, United States, China, Africa, Australia, India, and Southern Europe for its medicinal uses. The drugs derived from this plant find major markets in USA, Hungary, West Germany, Italy, The Netherlands, and UK [17-19].

MP is a tolerant plant against abiotic stresses such as drought and salinity, which can survive in a variety of habitats such as sandy soils, shrublands, grasslands, inland river banks, dunes in savannas, dry wastelands, houses, roadsides, and even beaches and limestone rocks all due to its hardiness. It can be found proliferating at a range of altitudes from 0 to 900 meters. MP prefers a soil $\mathrm{pH}$ of 5.5-6.5, can withstand salt up to $2000 \mathrm{ppm}$, and has excellent heat and drought tolerance. It thrives well in dry, frost-free, and humid environments with favorable moisture conditions, under full sun or partial shade, and in soils that are well-drained. It bears flowers and fruits the whole year in warm climates. MP cannot withstand too much water, wet soils, or a cool spring. Under adverse weather or in poorly drained soils, MP turns yellow-green while overwatering could lead to bacterial and fungal rot diseases of stem and root $[9,10,20]$.

\section{Genetics}

4.1. Cytology. The chromosome number of all species of the genus Catharanthus is $2 n=16[9,21,22]$ with a genome size of $1500 \mathrm{Mbp}$ (van Iren, unpublished). Doubling of chromosome number, tetraploidy, has been induced by colchicine treatment that resulted in an increase in TIAs, larger stomata, branches, and leaves, although there was reduced pollen fertility and poor seed set compared with diploid plants [23, 24].

4.2. Reproduction. MP is a unique species because of its self-compatibility unlike most of the other species in the family. However, intraflower self-pollination does not normally occur in periwinkle because of the physical separation between the stigma and anthers, a phenomenon known as reverse herkogamy, when the stigma is recessed below the level of anthers [25-28]. Even so, some periwinkles contain elongated ovaries or styles, thus allowing for intraflower self-pollination. Basically, MP is an allogamous (cross-pollinating) species. The degree of outcrossing varies with environmental conditions and the presence of seasonal pollinators, mainly butterflies and moths, whereby the floral structure is adapted to pollination by these long-tongued insects [29]. Self-incompatible strains of MP engage in natural interspecific hybridization which is found to be common locally in Madagascar $[18,30]$. But in all reality, both types of pollination occur in MP.

4.3. Genetic Diversity. Although many aspects of alkaloid biosynthesis have been investigated, the genetic variation between accessions in relation to alkaloid content and the effects of breeding for flower color or growth habit on the levels of vinblastine (VBL) and vincristine (VCR) are still poorly understood. Dissimilar cultivars accumulate TIAs in various parts of the plant. Hence, efforts need to be made to identify accessions out of the vast resources of naturally occurring MP germplasm for their chemotherapeutic potential, determine the type of plant tissues accumulating these active compounds, and administer genetic improvements for higher yield of alkaloids [31, 32]. A summary of genetic relatedness among $C$. roseus accessions based on different markers is shown in Table 2 .

\section{Agrotechnology}

5.1. Cultivation. Even though many investigations have been carried out over the last few decades on the phytochemical and therapeutic properties of MP, few studies have been conducted on the agronomic and genetic aspects of this herb. $\mathrm{MP}$ is very easy to cultivate. The seed germinates within a week in the dark. Seeds are easily sown directly or seedlings transplanted at a seeding rate of $2-3 \mathrm{~kg} / \mathrm{ha}$ and $0.5 \mathrm{~kg} / \mathrm{ha}$, respectively [33-35]. In a temperate climate, seeding takes place from March to April, the best temperature for seed germination being $25-30^{\circ} \mathrm{C}$. Seeds should be planted with a spacing of $45 \times 30 \mathrm{~cm}$ or $45 \times 45 \mathrm{~cm}$. Transplanting takes place between June and July or September and October in the case of 45-60-day-old seedlings spaced at $45 \times 20 \mathrm{~cm}$. Softwood stem cuttings or apical semiripe cuttings could also easily be grown in spring or summer under lighted conditions at $20^{\circ} \mathrm{C}$ and on drained compost $[19,36]$.

Effects of different levels of nitrogen application rates from 50 to $150 \mathrm{~kg} / \mathrm{ha}$ on plant yield have been tested with $150 \mathrm{~kg} / \mathrm{ha}$ giving the best response [37-41]. Root and shoot dry weights were greatest when high nitrate- $\mathrm{N}$ to ammonium- $\mathrm{N}$ ratio fertilizers were employed with high levels of ammonium-N having an adverse effect [20].

A planting density of 75000 plants/h and nutrient dose comprising a mixture of $15 \mathrm{t} /$ ha farm yard manure (FYM) plus $80 \mathrm{~kg} / \mathrm{ha} \mathrm{N}$ with irrigation (4-5 times) or $15 \mathrm{t} / \mathrm{ha} \mathrm{FYM}+$ $40 \mathrm{~kg} / \mathrm{ha} \mathrm{N}$ under rainfed conditions are recommended regimes in India. Dry yield (DY) was reported at $1.8 \mathrm{t} / \mathrm{ha}$ for leaves and $0.8 \mathrm{t} /$ ha for roots [42]. 3.06 t/ha DY could be obtained with $\mathrm{N}, \mathrm{P}\left(\mathrm{P}_{2} \mathrm{O}_{5}\right)$, and $\mathrm{K}\left(\mathrm{K}_{2} \mathrm{O}\right)$ application at a rate of $150: 40: 40 \mathrm{~kg} / \mathrm{ha}$ [40]. Mineral nutrition can increase the yield and the alkaloid content in periwinkle [43]. Nitrogen fertilization has been found to increase leaf and root yields, significantly. Alkaloids are nitrogenous compounds; therefore, nitrogen may play an important role in the biosynthesis and accumulation of alkaloids in plants [40]. 
TABLE 2: Genetic diversity in Catharanthus roseus accessions using different marker systems.

\begin{tabular}{|c|c|c|c|c|c|c|}
\hline NUA $^{1}$ & Type of marker(s) & $\begin{array}{l}\text { Clustering } \\
\text { method }\end{array}$ & $\begin{array}{l}\text { Similarity } \\
\text { indices }\end{array}$ & Ranges & $\begin{array}{c}\text { Genetic } \\
\text { variation }\end{array}$ & References \\
\hline 8 & $\mathrm{RAPD}^{2}$ & $\mathrm{UPGMA}^{7}$ & NP & $86-100$ & Low-moderate & {$[159]$} \\
\hline 8 & $\mathrm{AFLP}^{3}$ & UPGMA & NP & $85-100$ & Low-moderate & {$[159]$} \\
\hline 8 & ${ }^{1} \mathrm{H} \mathrm{NMR}^{*}$ & UPGMA & NP & $0-3$ & Moderate & {$[159]$} \\
\hline 8 & Chemical (ion content) & UPGMA & $\begin{array}{l}\text { Euclidean } \\
\text { distance }\end{array}$ & $32-100$ & High & {$[160]$} \\
\hline 14 & ISSR $^{4}$ & SAHN $^{8}$ & Jaccard & $0.57-1.00$ & Moderate & {$[161]$} \\
\hline 14 & RAPD & SAHN & Jaccard & $0.4-0.97$ & High & {$[161]$} \\
\hline 32 & Morphochemical/phytochemical & UPGMA & Nei’s & $55-100$ & Moderate & {$[131]$} \\
\hline 50 & Phytochemical/enzymatic & - & $\begin{array}{c}\text { Mean } \\
\text { comparison }\end{array}$ & - & High/moderate & {$[162]$} \\
\hline 72 & Isozyme/phytochemical & $\mathrm{NP}^{9}$ & $\begin{array}{c}\text { Mean } \\
\text { comparison }\end{array}$ & NP & Moderate & {$[30]$} \\
\hline 40 & ISSR & - & Nei’s & $0.15-0.9$ & High & {$[163]$} \\
\hline 9 & RAPD/ISSR/SSR ${ }^{5}$ & UPGMA & Jaccard & $0.19-0.73 / 0.25-0.64 / 0.26-0.73$ & High & {$[164]$} \\
\hline 32 & SSR/STMS ${ }^{6}$ & UPGMA & Nei and Li's & $0.07-0.79$ & High & [165] \\
\hline
\end{tabular}

${ }^{1}$ Number of used accessions, ${ }^{2}$ RAPD: random amplified polymorphic DNA, ${ }^{3}$ AFLP: amplified fragment length polymorphism, ${ }^{* 1} \mathrm{H}$ NMR: hydrogen-1 nuclear magnetic resonance, ${ }^{4}$ ISSR: intersimple sequence repeat, ${ }^{5}$ SSR: simple sequence repeat, ${ }^{6}$ STMS: sequence-tagged microsatellites sites, ${ }^{7}$ UPGMA: unweighted pair group method with arithmetic mean, ${ }^{8}$ SAHN: sequential agglomerative hierarchical nonoverlapping, and ${ }^{9} \mathrm{NP}$ : not presented in the related reference.

Planting distance $30 \times 20 \mathrm{~cm}$ produced the highest foliage and root yields [44]. Highest foliage yield was also reported at $45 \times 20 \mathrm{~cm}$ distance with an NPK $20: 30: 30 \mathrm{~kg} / \mathrm{ha}$ formulation [45]. An early June planting, spacing at $30 \times 50 \mathrm{~cm}$, NPK application of $150: 40: 30 \mathrm{~kg} / \mathrm{ha}$, and a late September harvest are recommended for higher yields in Iran [41]. The best sowing date under temperate climatic conditions in Poland is the second half of May, an optimum planting distance is 60 $\times 60 \mathrm{~cm}$, while harvesting in early September is ideal $[19,46]$.

5.2. Wild Types and Breeding Synthetic Cultivars. There are two types of MP in the wild, one with pink flowers and reddish stems and the other white flowers and green stems often found growing sympatrically. MP has been bred since the 1920s [47]. Over the past two decades, conventional breeding techniques conducted by horticulturists and seed companies entailed crossing $C$. roseus with other species that resulted in a large number of marvelous new cultivars or varieties. Breeding not only improved floral traits such increasing color range, blooms, and size; enhancing plant growth; augmenting tolerance to disease and cooler growing conditions, but also boosted herbage and alkaloid yield. For example, Dhawal white flower cultivar not only produces a higher plant and alkaloid yield, but also is dieback-tolerant [48]. Nirmal white flower cultivar can endure salt and fungal infection by Pythium aphanidermatum and Phytophthora nicotianae [15] and possesses a coveted leafless inflorescence (lli) architecture that increased the flower frequency [49].

The different cultivars are usually arranged in series, and subsequent grouping is based on corolla color [50]. Periwinkle plants now are readily available for gardeners worldwide in pink, deep rose, red, scarlet, white, white with a red eye, lavender blue, peach, apricot, orchid, burgundy, and many other shades. An international register of Catharanthus cultivars was published in 1998. There are few reliable compendia on this topic, and reliance has to be placed on information from the web. Series and cultivars of MP $[10,47$, 51-54] are presented in Tables 3 and 4, respectively. There are also nonseries selections that include Apricot Delight, Blue Pearl, Parasol, Morning Mist, Merry-Go-Round, Fanfare Orchid, Dwarf Little Salmon [55], Pink Panther [56], Santa Fe [57], and Snow Flake.

There have been numerous studies performed on two varieties, rosea and alba, of MP. All the results revealed that rosea is superior to alba in the overall performance of the plant. Rosea has higher alkaloid content in leaves and roots and more antioxidant activity than alba; rosea fared much better under water stress [58-60]. Triadimefon treatment increased the antioxidant potential and alkaloid ajmalicine content in rosea more than in alba [61].

5.3. Horticulture. MP is an easy growing and spreading per ennial herb that has multitudinous horticultural uses: decoration, annual ground cover, bedding, edging, border, container gardening, mass planting, naturalizing, hanging basket, and wall cascade. Surprisingly, the herb is naturalised for medicinal purposes in many parts of the world while it is considered as a weed or as an ornamental plant in the other parts. This conflict is the result of the MP's long history as a horticultural variety, especially over the past two centuries [62]. Horticultural practices caused changes in the distribution and biology of MP and this, in turn, generated changes in people's valuation of the species [62]. The new lines are novel in displaying an increased number of flowers on the inflorescence unhindered by leaves. In the new floricultural lines the overflowering "LLI" trait was combined 
TABLE 3: Catharanthus roseus series.

\begin{tabular}{|c|c|}
\hline Series & Characteristics \\
\hline Carpet & Height: $3-4$ inches $(7.6-10.2 \mathrm{~cm})$, width: 24 in $(60 \mathrm{~cm})$, dwarf, great for groundcovers, blooms all summer. \\
\hline Cobra & $\begin{array}{l}\text { Height: } 6-12 \text { in }(15-30 \mathrm{~cm}) \text {; spacing: } 6-9 \text { in }(15-22 \mathrm{~cm}) \text {, flower size: } 5-6 \mathrm{~cm} \text {, compact, drought-tolerant, suitable } \\
\text { for xeriscaping and growing in container. }\end{array}$ \\
\hline Cooler & $\begin{array}{l}\text { Height: } 10-14 \text { in }(30-35 \mathrm{~cm}) \text {, spread: } 15-20 \mathrm{~cm} \text {, low growing compact plants, more tolerant of cool, wet } \\
\text { conditions, vibrant colors. }\end{array}$ \\
\hline Cora & $\begin{array}{l}\text { Height: } 14-16 \text { in }(35-40 \mathrm{~cm}) \text {, width } 22-25 \text { in }(55-62 \mathrm{~cm}) \text {, large bold bright flowers, first series to be resistant to } \\
\text { the "sudden death," bloom early, heat tolerant, Disease-resistant to the fungus (Phytophthora) causing aerial } \\
\text { blight. }\end{array}$ \\
\hline Heat Wave & $\begin{array}{l}\text { Height: 14-20 inches, remarkable tolerance to heat and drought, blooms early, suitable for containers or hanging } \\
\text { baskets. }\end{array}$ \\
\hline First Kiss & Height: $10-14$ in $(28 \mathrm{~cm})$, compact, large-flowered (flower size: $6 \mathrm{~cm}$ ) and very heavy blooming. \\
\hline Jaio & Compact, vigorous, heat and drought tolerant, disease-resistant. \\
\hline Little & Height: 10 to 14 in, best used in small patio planters and decorative pots. \\
\hline Mediterranean & $\begin{array}{l}\text { Grows 5-6 inches tall, cascading habit, fairly vigorous, excellent heat and drought tolerance, performs well in } \\
\text { very warm conditions, many color combinations, good for use in hanging baskets or window boxes. }\end{array}$ \\
\hline Nirvana & Upright and cascading types, resistant to the fungus causing aerial blight. \\
\hline Pacifica & $\begin{array}{l}\text { Height: } 14-20 \text { in }(35-50 \mathrm{~cm}) \text {, spread } 15-20 \mathrm{~cm} \text {, open-pollinated group, blooms early, } 2 \text {-inch flowers with } \\
\text { overlapping petals, heat and humidity tolerant, more stress tolerant on the bench and in the garden, very } \\
\text { floriferous. }\end{array}$ \\
\hline Pretty & Height: 12 inches $(30.5 \mathrm{~cm})$, compact, multiflowered plants. \\
\hline Solar & $\begin{array}{l}\text { Heat and humidity tolerant, ideal for early sowings, early flowering, perfect for packs and pots, better disease } \\
\text { tolerant. }\end{array}$ \\
\hline Stardust & $\begin{array}{l}\text { Height: } 25-30 \mathrm{~cm} \text {, compact, many flowered, blooms have a star-shaped, solid white center and bright petal } \\
\text { border. }\end{array}$ \\
\hline Sunstorm & Large-flowered, compact and tolerant of both hot and cool growing conditions. \\
\hline Titan & $\begin{array}{l}\text { Height: up to } 16 \text { in }(35-40 \mathrm{~cm}) \text {, spread } 10-12 \text { in }(25-30 \mathrm{~cm}) \text {, bushy growing habit, vigorous, more } \\
\text { disease-resistant than other Vinca series, cool and drought tolerant, earlier flowering, has neat mounding } \\
\text { habits, large-flowered, flowers profusely, highest seed quality. }\end{array}$ \\
\hline Tropicana & Height 14-20 in, fast-growing, blooms early, large rounded flowers, heat and humidity tolerant. \\
\hline Tutti Frutti & Large-flowered, heat and drought tolerant. \\
\hline Victory & $\begin{array}{l}\text { Height: } 25-35 \mathrm{~cm} \text {, spread } 15-20 \mathrm{~cm} \text {, intense, clear colors, compact growing habit, disease tolerance, low and } \\
\text { early basal branching, formed large round flowers with overlapping petals. }\end{array}$ \\
\hline Viper & Height: $20-50 \mathrm{~cm}$, F1 Viper is the king of Vinca-vigorous, large mounded plant covered in massive flowers. \\
\hline Vitesse & eight: $32-35 \mathrm{~cm}$, compact with basal branching, ideal for early planting. \\
\hline
\end{tabular}

with variation in plant height, petal and eye colors, and tolerance to the common fungal diseases [60].

5.4. Model Plant in Phytopathology. MP acts as a unique host for a series of microorganisms such as bacteria and fungi. Hence, the herb serves as a model plant for studying the biology of microbial pathogenesis. As an invaluable model indicator plant for mollicutes in plant pathology, MP has no peers. It is an excellent experimental host for most phytoplasmas and spiroplasmas where high titres are achieved [63]. MP is highly susceptible to phytoplasma infection from different crops and exhibits highly distinctive symptoms such as phyllody and virescence. This popular herb is commonly used as a source plant to maintain mollicutes by grafting, dodder, or vector transmission. Infecting mollicutes induce symptoms on this experimental host similar to those on the original hosts [64]. MP has also been used as a model plant to study the interaction between the endophytes Methylobacterium mesophilicum and Xylella fastidiosa [65].

\section{Diseases and Management}

6.1. Diseases. Periwinkle plants are known to be susceptible to the aster yellows (16SrI) group phytoplasma in Argentina [66], Egypt [67], India [68], Malaysia [69, 70], and Myanmar [71] and have also been found to be naturally infected with spirea stunt (16SrIII-E), peach yellow leaf roll (16SrIII-A), clover proliferation (16SrVI), potato witches' broom (16SrVIA) [72], Mexican periwinkle virescence (16SrXIII) [73], and Malaysian periwinkle virescence (16SrXXXII) [74, 75]. MP 
TABLE 4: Available cultivars of Catharanthus roseus.

\begin{tabular}{|c|c|}
\hline Series & Cultivars \\
\hline Carpet & Rose Carpet, Pink Carpet, Magic Carpet. \\
\hline Cobra & $\begin{array}{l}\text { Cobra Apricot, Cobra Orchid W/Eye, Cobra Passion Fruit, Cobra Peppermint, Cobra Purple, Cobra Purple } \\
\text { W/Eye, Cobra Red, Cobra Red W/Eye, Cobra Rose, Cobra Strawberry Red, Cobra White. }\end{array}$ \\
\hline Cooler & $\begin{array}{l}\text { Cooler Apricot; Cooler Blush; Cooler Coconut; Cooler Deep Orchid, Cooler Grape; Cooler Hot Rose, Cooler } \\
\text { Icy Pink; Cooler Lavender Halo, Cooler Mixture, Cooler Orchid; Cooler Orchid Deep, Cooler Peppermint; } \\
\text { Cooler Peppermint Improved; Cooler Pink; Cooler Raspberry Red; Cooler Red; Cooler Rose; Cooler } \\
\text { Strawberry. }\end{array}$ \\
\hline Cora & $\begin{array}{l}\text { Cora Apricot, Cora Burgundy, Cora Deep Lavender, Cora Lavender, Cora Mix, Cora Pink, Cora Punch, Cora } \\
\text { Violet, Cora White, Cora Cascade Cherry, Cora Cascade Lilac, Cora Cascade Polka Dot. }\end{array}$ \\
\hline Heat Wave & $\begin{array}{l}\text { Heatwave Apricot, Heatwave Blue W/Eye, Heatwave Burgundy, Heatwave Cherry, Heatwave Deep Rose, } \\
\text { Heatwave Formula Mixture, Heatwave Grape, Heatwave Midnight Mix, Heatwave Orchid, Heatwave Peach, } \\
\text { Heatwave Peppermint, Heatwave Pink, Heatwave Raspberry, Heatwave Red, Heatwave Rose, Heatwave Santa } \\
\text { Fe, Heatwave Southwest Mix, Heatwave White. }\end{array}$ \\
\hline First Kiss & $\begin{array}{l}\text { First Kiss Apricot, First Kiss Blueberry, First Kiss Blush, First Kiss Cherry red, First Kiss Coral, First Kiss Icy } \\
\text { Pink, First Kiss Orchid, First Kiss Peach, First Kiss Polka Dot, First Kiss Raspberry, First Kiss Rose, First Kiss } \\
\text { Ruby, First Kiss Sunrise, First Kiss Think Pink, First Kiss White. }\end{array}$ \\
\hline Jaio & Jaio Dark Red, Jaio Scarlet Eye. \\
\hline Little & Little Blanche; Little Bright Eye; Little Delicata; Little Linda; Little Pinkie. \\
\hline Mediterranean & $\begin{array}{l}\text { Mediterranean Apricot Broadeye, Mediterranean Cherry Red Halo, Mediterranean Dark Red, Mediterranean } \\
\text { Deep Rose; Mediterranean Deep Orchid; Mediterranean Halo Mix, Mediterranean Lilac; Mediterranean Mix, } \\
\text { Mediterranean Peach Improved, Mediterranean Peach XP, Mediterranean Pink, Mediterranean Polka Dot; } \\
\text { Mediterranean Red, Mediterranean Rose, Mediterranean Rose Red, Mediterranean Rose Hot, Mediterranean } \\
\text { White Broadeye; Mediterranean White, Mediterranean Strawberry. }\end{array}$ \\
\hline Nirvana & $\begin{array}{l}\text { Nirvana Cascade Lavender W/Eye, Nirvana Cascade Orchid, Nirvana Cascade Pink Splash, Nirvana Cascade } \\
\text { Rose, Nirvana Cascade Shell Pink, Nirvana Cascade White, Nirvana Pink Blush, Nirvana Red, Nirvana Dark } \\
\text { Red. }\end{array}$ \\
\hline Pacifica & $\begin{array}{l}\text { Pacifica Apricot, Pacifica Blush, Pacifica Burgundy, Pacifica Burgundy Halo, Pacifica Burgundy; Pacifica Cherry } \\
\text { Halo, Pacifica Cherry Red; Pacifica Coral; Pacifica Dark Red, Pacifica Deep Orchid; Pacifica Icy Pink; Pacifica } \\
\text { Lilac; Pacifica Lipstick Mix, Pacifica Magenta Halo, Pacifica Mix, Pacifica Orchid Halo; Pacifica Peach; Pacifica } \\
\text { Pink; Pacifica Polka Dot; Pacifica Punch; Pacifica Punch Halo, Pacifica Raspberry, Pacifica Really Red, Pacifica } \\
\text { Red, Pacifica Rose Halo, Pacifica Pure White. }\end{array}$ \\
\hline Pretty & Aureo-variegata, Bowles. \\
\hline Solar & $\begin{array}{l}\text { Solar Apple Blossom, Solar Apricot, Solar Blueberry, Solar Blush Pink, Solar Cherry with Eye, Solar Formula } \\
\text { Mixture, Solar Fresh Red, Solar Lilac, Solar Orange with Eye, Solar Orchid with Eye, Solar Pink, Solar } \\
\text { Raspberry with Eye, Solar Red, Solar Red with Eye, Solar White. }\end{array}$ \\
\hline Stardust & Stardust Orchid; Stardust Pink, Stardust Mix, Stardust Rose. \\
\hline Sunstorm & $\begin{array}{l}\text { Sunstorm Apricot; Sunstorm Bright Red; Sunstorm Blush; Sunstorm Lilac; Sunstorm Orchid; Sunstorm Pink; } \\
\text { Sunstorm Rose W/Eye; Sunstorm Violet W/Eye; Sunstorm White W/Eye. }\end{array}$ \\
\hline Titan & $\begin{array}{l}\text { Titan Apricot, Titan Blush, Titan Burgundy, Titan Cotton Candy Mix, Titan Dark Red, Titan Icy Pink, Titan } \\
\text { Lavender Blue Halo, Titan Lilac, Titan Mix, Titan Polka Dot, Titan Punch, Titan Pure White, Titan Rose, Titan } \\
\text { White. }\end{array}$ \\
\hline Tropicana & Tropicana Apricot, Tropicana Blush; Tropicana Bright Eye; Tropicana Pink; Tropicana Rose. \\
\hline Tutti Frutti & Agastache, Rose. \\
\hline Victory & $\begin{array}{l}\text { Victory Apricot, Victory Blue, Victory Bright Eye, Victory Carmine, Victory Carmine Rose, Victory Cranberry, } \\
\text { Victory Deep Apricot, Victory Deep Pink, Victory Grape, Victory Lavender, Victory Light Pink, Victory Pure } \\
\text { White, Victory Purple, Victory Red. }\end{array}$ \\
\hline Viper & $\begin{array}{l}\text { Viper Apricot, Viper Grape, Viper Orchid Halo, Viper Pink, Viper Purple, Viper Purple Halo, Viper Red, Viper } \\
\text { Red W/Eye, Viper Rose, Viper Watermelon. }\end{array}$ \\
\hline Vitesse & $\begin{array}{l}\text { Vitesse Apricot, Vitesse Blush, Vitesse Cranberry, Vitesse Fuchsia, Vitesse Grape, Vitesse Hot Pink, Vitesse } \\
\text { Lavender, Vitesse Orange, Vitesse Orchid, Vitesse Peach, Vitesse Peppermint, Vitesse Pink, Vitesse Purple, } \\
\text { Vitesse Raspberry, Vitesse Red W/Eye, Vitesse Rose, Vitesse Strawberry Red, Vitesse Strawberry Twist, Tropical } \\
\text { Orange, Vitesse White. }\end{array}$ \\
\hline
\end{tabular}


was the first nonrutaceous plant found naturally infected with Spiroplasma citri in the United States [76]. This pathogen was subsequently discovered in Mediterranean countries, including Morocco, Syria, Cyprus, and Turkey [77], and in Southeast Asia, Malaysia [78]. Periwinkle is also known to be susceptible to the cucumber mosaic virus (CMV), and disease incidence has been reported in Australia [79], India [80], and Malaysia [81].

Bedding plants such as periwinkle are susceptible to many damping-off diseases. MP is prone to blight, canker, leaf spot, and root rot. Pathogenic fungi include Alternaria (leaf spot), Rhizoctonia solani (stem, crown, and root rot), and Phytophthora parasitica Dast. (foliars and stems). P. parasitica, a soilborne fungus, causes serious losses and death in the periwinkle with reports from India and the United States [8285]. Fusarium root rot has been reported from Taiwan [86]. Blight caused by $P$. nicotianae (syn. $=$ P. parasitica) is one of the most damaging diseases of MP in Florida [87]. Other known blights include twig blight caused by Colletotrichum dematium [88], foliar blight brought about by P. tropicalis in Virginia [89], and gray mold blight affected by Botrytis cinerea in the United States, Italy, and Taiwan [90-92]. Other fungi identified to incite disease in periwinkle seedlings in Taiwan include Botrytis cinerea, Colletotrichum gloeosporioides, Fusarium oxysporum, F. solani, P. parasitica, Pythium aphanidermatum, Rhizoctonia solani, Sclerotinia sclerotiorum, and Sclerotium rolfsii [92]. Black root rot through Thielaviopsis infection is the most serious root disease in MP because it is very difficult to control [47]. Periwinkle rust due to Puccinia vincae attack (http://donsgarden.co.uk/) is another disease to be noted. Fungal problems can occur under humid or wet conditions so care has to be exercised to prevent overwatering. Insect pests are no major concern, although aphids, thrips, spider mites, mealy bugs, and scale insects can infest this plant [47].

6.2. Disease Management. Environmentally, a full-sun planting location reduced humidity levels, and increased air circulation around the plants should be targeted. Potting mixes have to be pathogen-free and new containers prepared for each planting. Sanitation-wise, weeds should be kept down, infected soils and plants removed immediately upon detection, all equipment kept clean, and the planting area cleared of old potting media and plant debris. In fertilization and irrigation, avoid heavy fertilization and overwatering of plants. Overhead irrigation and prolonged periods of leaf wetness should be avoided with watering done only during the day. Soil fertility has to be properly adjusted to $\mathrm{pH}$ maintained at 5.5. Transplants need to be spaced at least 10-12 inches apart. Biocontrol of soilborne fungal pathogens could be attempted with Trichoderma virens, binucleate Rhizoctonia, or Burkholderia cepacia [47, 87, 93-96].

\section{Phytochemistry}

Two commercially and pharmacologically important cytotoxic dimeric alkaloids of MP, vinblastine and vincristine, have been widely used for cancer chemotherapy, which are only present in extremely low yields in the leaves [31].
The three-dimensional structure of these two compounds has been featured in Figures 2(a)-2(b). In addition to alkaloids and phenolics (as the most important compounds of MP), the presence of different chemical groups such as polyphenols, alkaloids, steroids, flavonoid glycosides, anthocyanins, and iridoid glucosides has been confirmed in different parts of MP [97]. However, some evidence implicates the availability of similar compounds in the leaves and stems of the plant, but the same does not comply with the contents of seeds and petals [98]. Flower extract of MP has been used as a natural acid-base indicator $[99,100]$.

7.1. Major Alkaloids. All parts of the plant contain several active alkaloids with an indole moiety. More than 130 indole alkaloids, collectively termed terpenoid indole alkaloids (TIAs), have been extracted from periwinkle [31, 101-104]. Some of these alkaloid compounds have distinct medicinal properties. The alkaloid content is highest at the flowering stage [50]. The principal alkaloids present in the aerial (nonfloral) parts are VBL (vincaleukoblastine, VLB), VCR (leurocristine, vincaleurocristine), vincarodine, vincoline, leurocolombine, viramidine, vincathicine, vincubine, isositsirikine, vincolidine, lochrovicine, catharanthine, vindoline, leurosine, lochnerine, tetrahydroalstonine, and vindolinine. Ajmalicine (raubasine), serpentine, and reserpine are the main alkaloids in the root while coronaridine, 11-methoxy tabersonine, tetrahydroalstonine, ajmalicine, vindorosidine, and vincristine dominate in the flower. However of the over hundred alkaloids discovered, only five consisting of vinblastine, vincristine, $3^{\prime}, 4^{\prime}$-anhydrovinblastine, serpentine, and ajmalicine are marketed [102]. Other Catharanthus species such as C. longifolius, C. trichophyllus, and C. lanceus are known to possess vindoline type alkaloids.

7.2. Major Phenolics. Phenolic compounds are a group of metabolites available in all plant species. These compounds can range from simple compounds bearing just one phenolic hydroxyl to some more complex ones, like flavonoids, which are often polyphenols. Besides alkaloids, MP produces a wide spectrum of phenolic compounds with radical scavenging ability, including $\mathrm{C} 6 \mathrm{Cl}$ compounds such as 2,3dihydroxybenzoic acid, as well as phenylpropanoids such as cinnamic acid derivatives, flavonoids, and anthocyanins [97]. Mustafa and Verpoorte [97] have listed the most important phenolic compounds of MP, including 2,3-DHBAG, SA; SAG, benzoic acid, 2,5-DHBA, and 2,5-DHBAG, gallic acid, glucovanillin, vanillic acid, glucovanillic acid, vanillyl alcohol, vanillyl alcohol-phenyl-glucoside, C6C3/conjugated C6C3: trans-cinnamic acid, hydroxytyrosol, ferulic acid, chlorogenic acid, C6C3C6/conjugated C6C3C6: kaempferol, trisaccharides, quercetin, syringetin glycosides, malvidin, malvidin 3-O-glycosides, malvidin 3-O-(6-O-p-coumaroyl), petunidin, petunidin 3-O-glucosides, and petunidin 3-O-(6O-p-coumaroyl).

\section{Phytobioactivity}

8.1. Ethnobotanical Importance. Decoctions of MP are mentioned in folklore remedies for treatment of diabetes, malaria 


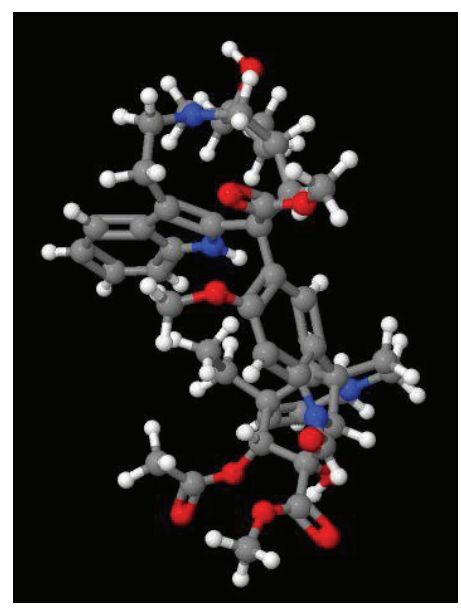

(a)

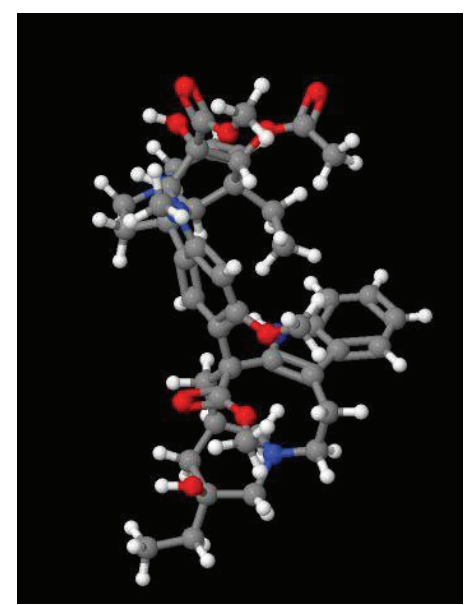

(b)

FIGURE 2: The three-dimensional structures of the main anticancer compounds of MP, (a) vincristine and (b) vinblastine, in a ball-stick model (http://www.chemspider.com/ImageView).

[105], dengue fever, dysentery [106], insect bites [107], skin infection, diarrhea, leukemia, eye irritation, dyspepsia, dysentery, toothache, sore throat, and lung congestion [106]. The root of the plant is reported to be a tonic and possess hypotensive, sedative, and tranquillizing properties [108]. In Ayurveda, it is used for treating diabetes. Hypoglycemic activity of aqueous extracts from MP has been proved in modern studies, as well [109]. In Madagascar, the bitter and astringent leaves have been applied as an emetic; roots have been used as a purgative, vermifuge, depurative, hemostatic agent and toothache remedy. In the Philippines, the leaf decoction is an herbal treatment for diabetes, young leaves are for stomach cramps, and root decoction is for intestinal parasitism. Mauritians employ infusion of leaves for indigestion and dyspepsia. In India (Orissa and Assam), juices from the leaves are used to treat wasp stings while roots and leaves are utilized as anticarcinogenic agents $[18,110]$.

MP floral extracts enjoy wide usage in many countries as a remedy for many ailments: Cuba and Jamaica: eyewash for infants; Bahamas: asthma; Bermuda: high blood pressure; Indo-China: dysmenorrhea; Surinam and throughout the Caribbean: eye irritation/infections, malaria, menstrual pains, and diaphoresis. Ugandans put faith in leaf infusions to treat stomach ulcers while Batswana ground leaves in milk for mature abscesses. In Togo, a root decoction is taken to treat dysmenorrhoea $[18,110]$. Even in developed countries such as Europe, MP is used as a folk remedy for diabetes for centuries. In Hawaii, the plant is boiled to make a poultice stop bleeding. The Chinese have widely applied this versatile herb in the treatment of leukemia, hypertension, lymphosarcoma, and giant follicular lymphoma while adapting it as an astringent, diuretic, and cough remedy. Similarly, in central and south America, it is popular as a homemade cold remedy to ease lung congestion, inflammation, and sore throat while it is trusted as an alternative medical treatment source for leukemia in Hong Kong and Korea. Japan has targeted MP for arresting diabetes and malignant lymphatic tumours [111]. In addition, modern research has revealed a broad spectrum of medicinal applications for the herb (Table 5).

8.2. Toxicity and Side Effects. MP can be dangerous if consumed orally. It can be hallucinogenic and is cited as such (under its synonym Vinca rosea) in the Louisiana State Act 159. TIAs have been applied clinically since the end of the 1950s as major drugs in the treatment of acute lymphoblastic leukemia, non-Hodgkin lymphomas, myeloma, and Hodgkin lymphoma [112]. Despite their benefits, all of the MP alkaloids have neurotoxic activity, especially vincristine, affecting neurotransmission [113]. Vincristine and vinblastine are highly toxic antimitotics, blocking mitosis in metaphase after binding to the microtubules [114]. Moreover, many side effects have been reported for these drugs comprising myelosuppression, alopecia, abdominal cramps, constipation, nausea/vomiting, paralytic ileus, ulcerations of the mouth, hepatocellular damage, kidney impairment, pulmonary fibrosis, urinary retention, amenorrhoea, azoospermia, orthostatic hypotension, and hypertension $[113,115,116]$. The dosage and administration must be carefully controlled to reduce side effects [112].

8.3. Formulations and International Trade. The two key pharmaceutical dimeric alkaloid compounds, VBL and VCR, exist mainly in the aerial parts of the plant in extremely low concentrations, the latter quantitatively much less than the former [50, 117-119]. Vincristine sulfate, originally known as leurocristine, is the only effective antileukemic drug that reduces white blood cell count drastically; since the 1950 s, it has increased the survival rate of children with leukemia from $20 \%$ to $80 \%$. It is one of the most expensive plant products on the market with considerable side effects. Vinblastine similarly decreases the quantity of white blood cells in the blood [112]. Vinblastine sulfate has now been marketed for more than 40 years as an anticancer drug. It has proven effective against Hodgkin's disease. Vincristine sulfate and vinblastine 
TABLE 5: List of the most important studies on the medicinal effects of Catharanthus roseus.

\begin{tabular}{|c|c|c|c|}
\hline \multirow{2}{*}{ Application } & \multicolumn{2}{|c|}{ Modern researches } & \multirow{2}{*}{ References } \\
\hline & In vitro & In vivo & \\
\hline $\begin{array}{l}\text { Acetylcholinesterase and cholinergic } \\
\text { antagonism inhibition }\end{array}$ & Microplate assay & Male Wistar rats* & {$[166,167]$} \\
\hline Alzheimer's syndrome & & Human (clinical trial) & [168] \\
\hline Anthelminthic activity & Pheretima posthuma & & [169] \\
\hline Antiandrogenic activity & Mice & & {$[170]$} \\
\hline Antiangiogenesis activity & Chicken eggs & & {$[171]$} \\
\hline Antibacterial (antiseptic) activity & Bacteria & & {$[106,172-175]$} \\
\hline Antidysenteric activity & Wistar rats & & {$[176]$} \\
\hline Antifertility effect & Male rat & & {$[115,177,178]$} \\
\hline Antifungal activity & $\begin{array}{l}\text { Trichophyton rubrum } \\
\text { Hendersonula toruloidea }\end{array}$ & & {$[179,180]$} \\
\hline Antihyperglycemic activity (antidiabetic) & Mice, rat, rabbit & Wistar albino rats & {$[109,181-188]$} \\
\hline $\begin{array}{l}\text { Antihypercholesterolemic activity } \\
\text { (antihyperlipidemic) }\end{array}$ & Rabbit, rat & & {$[184,189]$} \\
\hline Anti-inflammatory activity & Rat & & {$[189]$} \\
\hline Antimutagenic activity & Micronucleated erythrocytes & & {$[190]$} \\
\hline Antineoplastic activity & Mice, rat & Clinical use & {$[113,191-198]$} \\
\hline Antioxidant activity & Rat & & {$[61,184,199]$} \\
\hline Antiplasmodial activity & Human erythrocytes & & {$[200,201]$} \\
\hline Antiproliferative activity & Human cells & & {$[202,203]$} \\
\hline Antispermatogenic & Male rat, mice & & {$[204,205]$} \\
\hline Blood cleanser & & & {$[206]$} \\
\hline Cytochrome P450 inhibition & CYP2D6 & & {$[207]$} \\
\hline Cytotoxic activity & Human cell line & & {$[208,209]$} \\
\hline Enhances kidney and liver functions & Wistar rat & & {$[185,210]$} \\
\hline Epididymal dysfunction & Rat & & {$[211]$} \\
\hline Generate giant spermatogonial cells & Albino rat & & {$[212]$} \\
\hline Hypotensive activity & Rat & & {$[108]$} \\
\hline Larvicidal activity & $\begin{array}{l}\text { Anopheles stephensi (malaria } \\
\text { vector); Aedes aegypti }\end{array}$ & & {$[213,214]$} \\
\hline $\begin{array}{l}\text { Regression of accessory reproductive } \\
\text { organs }\end{array}$ & Male Wistar rats & & {$[215]$} \\
\hline Regression of entire reproductive system & Male rat & & [216] \\
\hline Stomachic & - & & {$[108,217]$} \\
\hline Tonic & - & & {$[108,217]$} \\
\hline Tranquilizing and sedative action & - & & {$[101,108,217]$} \\
\hline Wound healing & Rat & & [218] \\
\hline
\end{tabular}

sulfate are being sold for a total US\$ 100 million per year $[50,120]$. Developing food stuff incorporated by fresh leaves of MP gives rise to the economic importance of the herb while such products possess both pharmaceutical and nutritional properties, simultaneously [121].

These injectable drugs and their semisynthetic analogues such as vinorelbine (VRLB) and vindesine (VDS) interfere with the division of cancer cells [31, 122-126]. Navelbine $\left(5^{\prime}\right.$-noranhydrovinblastine) is a semisynthetic vinca alkaloid with complete microtubule depolymerization ability, broader antitumor activity, and a lower neurotoxicity than VBL and VCR because it selectively interferes with tubulin assembly [127]. Fully synthetic vincristine is far less efficient (only $20 \%$ efficiency) compared to the natural product derived from MP, and hence the importance of the species and its bioactive compounds is unchallenged owing to their complex structures [119]. The other valuable therapeutic alkaloid "ajmalicine" is a constituent of hypotensive drugs employed 
in the treatment of high blood pressure. Two to three hundred tons of MP roots is required for $3600 \mathrm{Kg}$ annual world production of ajmalicine [119].

\section{Promising Horizons in Biosynthesis of the Phytochemicals}

9.1. TIAs Pathways Studies. There are two different metabolic pathways for the biosynthesis of terpenoids leading to the formation of the $\mathrm{C}_{5}$ central precursor isopentenyl diphosphate (IPP), namely, the classical cytosolic mevalonate pathway and the mevalonate-independent plastidic 2-C-methyl-Derythritol 4-phosphate (MEP) pathway. The biosynthesis of MP TIAs starts with the condensation of tryptamine (shikimate pathway) and secologanin (MEP pathway) to form the key intermediate strictosidine, the common backbone structure of all TIAs [128]. However, the alkaloid pathway in $\mathrm{MP}$ and the involved genes remain partly unknown [128], but gene-to-metabolite networks studies for understanding the biosynthesis of TIAs in MP using the cDNA-amplified fragment length polymorphism (AFLP) markers have revealed valuable information [129]. At the same time, the drawn networks increase the practical potential of metabolic engineering of MP.

9.2. Cell and Tissue Culture. VBL and VCR are only produced in very low concentrations in MP. The high therapeutic value and cost of production of the minute amounts of these bisindole alkaloids (VBL and VCR) have prompted extensive efforts to increase their levels by cell-tissue culture and mutation induction [130-132]. In vitro methods such as cell suspension, hairy root and callus cultures, shoot cultures, metabolic engineering, and regulation studies to improve the phytochemicals production are uncontested shortcut strategies to those time-consuming conventional breeding methods. In other words, when there is a high demand for plant-based pharmaceutics and only low amounts accumulate in plants, plant cell cultures have shown to be an efficient alternative production system of valuable phytochemicals on a large scale. Rapid reproduction and preservation of natural sources are of the beneficial points of such an approach [133]. Plant growth regulators (PGRs) activate plant natural defence mechanisms, thereby leading to increase the biosynthesis of the secondary metabolites in plants. In this regard, application of PGRs like methyl jasmonate (MeJA), dimethyl sulfoxide (DMSO), jasmonates, and salicylic acid as elicitors of secondary metabolites has led to positive results, in recent experiments [128, 134, 135]. Isolation of VBL and VCR using callus culture [136], cell culture [137], shoot culture [138], semisynthetic [139] and totally synthetic approaches [140] is currently considered. Unfortunately, drug supplementation using the aforementioned techniques is limited and cannot meet the existing requirements. Application of artemisinic acid as a useful elicitor has recently been highlighted in suspension-cultured cells of MP [141].

9.3. Plant-Fungal Symbiotic Fashion. As mentioned, despite a nonstop explorative trend, the desired level of production of the bioactive compounds such as VBL and VCR has still not been achieved at optimum level [142]. For this reason, isolation of endophytic fungi from the MP plant has been taken into consideration as an alternative solution, more recently [143]. Investigations on the pathobiology of the species have led to very exciting results. Mechanistically, endophytic fungi reside in a symbiotic fashion inside periwinkle plant, imitate their chemistry, and produce the same natural products as their hosts and are thus being screened for the production of the most valuable anticancer compounds of the herb, namely, VBL and VCR. In line with this, researchers took the first steps toward producing VCR using Fusarium oxysporum, an endophyte of MP [144, 145]. Later on, Guo and Kunming [146] obtained VBL by Alternaria species isolated from the same plant found in China and showed the production based upon thin layer chromatography (TLC) and high performance liquid chromatography (HPLC) only. Eventually, the latest innovation in this area happened by employing the same endophytic fungus (F. oxysporum; strain AA-CRL-6), for isolation of both anticancer compounds VBL and VCR in appreciable amounts, successfully [147].

9.4. Functional Genomics and Proteomics Exploration. The biosynthesis of VBL includes more than 20 enzymatic phases, in which nine out of 20 are now well characterized at the enzyme and gene level, and several regulatory genes of the pathway (ORCAs) have also been cloned [148]. Proteomic analysis of the plant using two-dimensional electrophoresis led to the identification of 58 proteins, including two isoforms of strictosidine synthase (EC 4.3.3.2), which catalyze the formation of strictosidine in the alkaloid biosynthesis; tryptophan synthase (EC 4.1.1.28), which is required as a supplying source of the alkaloid precursor tryptamine; 12oxophytodienoate reductase, which is indirectly involved in the alkaloid biosynthesis as it catalyzes the last step in the biosynthesis of the regulator jasmonic acid [149]. Recently, scientists have detected a higher number of proteins using two-dimensional differential in gel electrophoresis (2D-DIGE) technique in two different lines of the herb, 358 proteins in one and 1663 in another line, most of which corresponded to housekeeping proteins or involved in primary metabolism [150]. Of these, a total of 63 enzymes only potentially involved in secondary metabolism, of which 22 were related to TIAs biosynthesis and 16 were predicted transporters putatively involved in secondary metabolite transport. As a matter of fact, these results are important steps towards elucidating the proteome of MP, which are essential to understanding the modality of TIAs biosynthesis [150].

9.4.1. Transformation of Specific Genes. Quantitative analysis of metabolic pathways in MP revealed that metabolically engineered hairy roots can lead to overproduction of TIAs [151]. Recent studies are focused on cloning, characterization, and transformation of the genes involved with the related biosynthetic cycles such as CrPrxl that belongs to an evolutionary branch of vacuolar class III peroxidases [148].

9.4.2. Transformation of Genes Affecting the Intermediate Compounds. Recent genetic engineering of MP not only is limited to the genes enhancing the VBL and VCR production 
directly, but also includes the genes augmenting the biosynthesis of the intermediate compounds such as vindoline, an important intermediate leading to VBL and VCR. Genes such as desacetoxyvindoline-4-hydroxylase-like ( $d 4 h$-like), ORCA3 (octadecanoid-derivative responsive Catharanthus AP2-domain), and G10H (geraniol 10-hydroxylase) are suitable examples of the aforementioned trend [152, 153].

\subsubsection{Application of Reverse Genetics for Gene Identification.} The concept of "reverse genetics" is widely used for characterization of plant enzymes (more precisely genes encoding enzymes involved in alkaloid metabolism) in which the partial sequencing of proteins is carried out after purification of the isolated enzymes from plants or plant cell culture by traditional biochemical chromatography techniques. These sequences are consequently used to identify the corresponding gene from a plant cDNA library [154]. Homology-based cloning of candidate genes and their succeeding functional testing in heterologous expression systems are hastening the pace at which the gene catalogues of alkaloid biosynthesis are developing. For example, putrescine N-methyltransferase, the first enzyme in the nicotine-specific pathway, and an isoflavone reductase-like enzyme putatively involved in nicotine biosynthesis are both expressed specifically in the cortex and endodermis of tobacco root tips. However, intense expression of these enzymes shifts to the xylem parenchyma and outer cortex cells in more differentiated parts of the root [155]. This developmentally regulated spatial expression pattern may be complicatedly associated with nicotine dissemination in tobacco tissues and organs. Tropane alkaloids, as well as nicotine, are mainly synthesized in the root and transported to aerial parts where they accumulate in vacuoles at high levels. Analysis of xylem saps taken from the stem shows that these alkaloids are transported via the xylem [156].

9.4.4. Promoter Engineering. The gene transformation procedure not only is limited to transferring the genes with the "constitutive" promoters, but also can be implemented by fusing the "regulated" promoters to the target gene. The best example of the mentioned process is the agrobacteriummediated transformation of the hydroxymethylbutenyl 4diphosphate synthase gene (HDS) from the methyl erythritol phosphate (MEP) pathway by replacing an HDS-GUS fused promoter with the constitutive CaMV35S promoter. The functional characterization of the transformed cells confirmed the induction of HDS promoter by several hormonal indicators (auxin, cytokinin, methyl jasmonate, and ethylene) leading to the MIAs production in MP [157].

9.4.5. Gene Silencing. Conceivably, one of the most advanced technologies to scrutinize the MIAs metabolism in MP is the virus-induced gene silencing (VIGS) strategy by establishing tobacco rattle virus- (TRV-) based approach [158]. Secologanin is a versatile iridoid and a precursor for the assembly of countless MIAs as well as a number of quinoline alkaloids. In a very recent attempt, employing the VIGSbased method led to the identification of the 7-deoxyloganic acid 7-hydroxylase $(\mathrm{CrDL} / \mathrm{H})$ gene involved in the third to the last step of secologanin biosynthesis [121]. Silencing the mentioned gene reduced the level of secologanin up to at least $70 \%$ and increased the level of 7-deoxyloganic acid to over $4 \mathrm{mg} \mathrm{g}^{-1}$ fresh leaf weight compared with the control plants in which this iridoid is not detected. Functional expression of this gene confirmed its priority as a specific substrate for 7-deoxyloganic acid compared to other related substrates. Therefore, it seems that hydroxylation precedes carboxy-Omethylation in the secologanin pathway leading to the MIAs biosynthesis in C. roseus [121].

\section{Conclusion}

Nowadays, the demand for natural products and plantbased medicines is growing throughout the world. MP is a remarkable herb owing to its broad spectrum of applications. Apart from its natural supply of anticancer compounds for medicine on the international market, it ranks highly as a popular ornamental plant in the horticultural industry and as a model plant for studies in phytopathology as well as biotechnology. The ultimate goal of current research is to produce MP disease-resistant cultivars with a high content of antitumor alkaloids. Several cultivars have been introduced primarily as ornamental plants with their alkaloid composition, agronomic performance, and genetic affiliations unknown. As such, agronomic and genetic elucidation of new cultivars with exploration of their physiology and secondary metabolism are required for achieving a high quantity and quality output of TIAs. It is unfortunate that MP anticancer drugs have several adverse side effects. This renders further exploration of the clinical pharmacokinetics of MP alkaloids and drug-drug interactions indispensable.

\section{Conflict of Interests}

The authors declare that there is no conflict of interests regarding the publication of this paper.

\section{References}

[1] M. Faheem, S. Singh, B. S. Tanwer, M. Khan, and A. Shahzad, "In vitro Regeneration of multiplication shoots in Catharanthus roseus - an important medicinal plant," Advances in Applied Science Research, vol. 2, pp. 208-213, 2011.

[2] F. E. Koehn and G. T. Carter, "The evolving role of natural products in drug discovery," Nature Reviews Drug Discovery, vol. 4, no. 3, pp. 206-220, 2005.

[3] A. Valdiani, M. A. Kadir, S. G. Tan, D. Talei, M. P. Abdullah, and S. Nikzad, "Nain-e havandi Andrographis paniculata present yesterday, absent today: a plenary review on underutilized herb of Iran's pharmaceutical plants," Molecular Biology Reports, vol. 39, no. 5, pp. 5409-5424, 2012.

[4] P. J. Facchini, "Alkaloid biosynthesis in plants: biochemistry, cell biology, molecular regulation, and metabolic engineering applications," Annual Review of Plant Biology, vol. 52, pp. 2966, 2001.

[5] P. J. Facchini and V. de Luca, "Opium poppy and Madagascar periwinkle: model non-model systems to investigate alkaloid 
biosynthesis in plants," The Plant Journal, vol. 54, no. 4, pp. 763$784,2008$.

[6] S. Kohlmüzer, "Alkaloids of Catharanthus roseus (L.) G. Dona new group of biologically active compounds," Postepy Biochemii, vol. 14, no. 2, pp. 209-232, 1968.

[7] J. Roepke, V. Salim, M. Wu et al., "Vinca drug components accumulate exclusively in leaf exudates of Madagascar periwinkle," Proceedings of the National Academy of Sciences of the United States of America, vol. 107, no. 34, pp. 15287-15292, 2010.

[8] D. Whiting, A. O’Connor, J. Jones, L. McMulkin, and L. Potts, "Taxonomic Classification," CMG GardenNotes, vol. 122, pp. 18, 2011.

[9] A. C. Plaizier, "A revision of Catharanthus roseus (L.) G. Don (Apocynaceae)," Mededelingen Landbouwhogeschool, vol. 81, no. 9, pp. 1-12, 1981.

[10] M. A. van Bergen, "Revision of Catharanthus roseus G. Don. series of revisions of Apocynaceae XLI," Agricultural University of Wageningen Papers, vol. 96, no. 3, pp. 9-46, 1996.

[11] IPNI (The International Plant Names Index), 2008, http://www. ipni.org/.

[12] Royal Botanic Gardens, Kew Resource Page, http://www.kew. org./data/subjects.html.

[13] USDA Plant Data Base, http://plants.usda.gov/.

[14] J. Aslam, S. H. Khan, Z. H. Siddiqui et al., "Catharanthus roseus (L.) G. Don. an important drugs: it's applications and production," Pharmacie Globale, vol. 4, no. 12, pp. 1-16, 2010.

[15] S. Chaudhary, V. Sharma, M. Prasad et al., "Characterization and genetic linkage mapping of the horticulturally important mutation leafless inflorescence (LLI) in periwinkle Catharanthus roseus," Scientia Horticulturae, vol. 129, no. 1, pp. 142-153, 2011.

[16] Y. Sreevalli, R. N. Kulkarni, and K. Baskaran, "Inheritance of flower color in periwinkle: orange-red corolla and white eye," Journal of Heredity, vol. 93, no. 1, pp. 55-57, 2002.

[17] P. P. Joy, J. Thomas, S. Mathew, and B. P. Skaria, Medicinal Plants, Kerala Agricultural University, 1998.

[18] PROTA, Plant Resources of Tropical Africa. African Ornamentals. Proposals and Examples, PROTA Foundation, Wageningen, The Netherlands, 2011.

[19] B. Łata, "Cultivation, mineral nutrition and seed production of Catharanthus roseus (L.) G. Don in the temperate climate zone," Phytochemistry Reviews, vol. 6, no. 2-3, pp. 403-411, 2007.

[20] P. A. Thomas and J. G. Latimer, "Growth of vinca as affected by form of nitrogen, presence of bark, and type of micronutrients," Journal of Plant Nutrition, vol. 18, pp. 2127-2134, 1996.

[21] G. V. A. Balamani and R. S. Rao, "In chromosome number reports LXXIII," Taxon, vol. 30, pp. 855-856, 1981.

[22] M. S. Mendioro, M. Q. D. Diaz, M. T. B. Alcantara, O. J. Hilario, P. Mateo, and R. D. M. Maghirang, "Cytological studies of selected medicinal plants: Euphorbia pulcherrina Willd. Ex Klotz., Moringa oleifera Lam., Catharanthus roseus (L.) Don., and Chrysanthemum indicum Linn," The Philippine Journal of Science, vol. 134, pp. 31-37, 2005.

[23] V. R. Dnyansagar and I. V. Sudhakaran, "Induced tetraploidy in Vinca rosea L," Cytologia, vol. 35, pp. 227-241, 1970.

[24] K.-X. Tang, S.-H. Xing, X.-B. Guo et al., "Induction and flow cytometry identification of tetraploids from seed-derived explants through colchicine treatments in Catharanthus roseus (L.) G. Don," Journal of Biomedicine and Biotechnology, vol. 2011, Article ID 793198, 10 pages, 2011.
[25] R. N. Kulkarni, Y. Sreevalli, K. Baskaran, and S. Kumar, “The mechanism and inheritance of intraflower self-pollination in self-pollinating variant strains of periwinkle," Plant Breeding, vol. 120, no. 3, pp. 247-250, 2001.

[26] R. N. Kulkarni, Y. Sreevalli, and K. Baskaran, "Allelic differences at two loci govern different mechanisms of intraflower selfpollination in self-pollinating strains of periwinkle," Journal of Heredity, vol. 96, no. 1, pp. 71-77, 2005.

[27] R. N. Kulkarni and K. Baskaran, "From herkogamy to cleistogamy-development of cleistogamy in periwinkle," Journal of Heredity, vol. 104, no. 1, pp. 140-148, 2013.

[28] Y. Sreevalli, K. Baskaran, R. N. Kulkarni, and S. Kumar, "Further evidence for the absence of automatic and intra-flower selfpollination in periwinkle," Current Science, vol. 79, no. 12, pp. 1648-1649, 2000.

[29] P. Albers and L. J. G. van der Maesen, "Pollination of Apocynaceae," Agricultural University Wageningen Papers, vol. 3, pp. 61-81, 1994.

[30] M. Sevestre-Rigouzzo, C. Nef-Campa, A. Ghesquière, and H. Chrestin, "Genetic diversity and alkaloid production in Catharanthus roseus, C. trichophyllus and their hybrids," Euphytica, vol. 66, no. 1-2, pp. 151-159, 1992.

[31] R. van der Heijden, D. I. Jacobs, W. Snoeijer, D. Hallard, and R. Verpoorte, "The Catharanthus alkaloids: pharmacognosy and biotechnology," Current Medicinal Chemistry, vol. 11, no. 5, pp. 607-628, 2004.

[32] R. Zárate and R. Verpoorte, "Strategies for the genetic modification of the medicinal plant Catharanthus roseus (L.) G. Don," Phytochemistry Reviews, vol. 6, no. 2-3, pp. 475-491, 2007.

[33] R. Gupta, "Periwinkle-produces anticancer drug," Indian Farming, vol. 7, pp. 11-13, 1977.

[34] S. K. Parrek, S. Singh, V. K. Srivastava, S. Mandal, M. L. Maheswari, and R. Gupta, "Advances in periwinkle cultivation," Indian Farming, vol. 31, pp. 18-21, 1981.

[35] A. Sadowska, G. Obidowska, and M. Szacho-Guchowicz, "Wpływ nawożenia NPK na masę ziela oraz zawartość alkaloidów u Catharanthus roseus (L.) G. Don," Biuletyn IHAR, vol. 170, pp. 55-63, 1989.

[36] M. Shamim, S. R. Voleti, R. L. Misra, and S. P. S. Raghava, "Influence of temperature on seed germination in three ornamental species," Journal of Ornamental Horticulture, vol. 2, pp. 89-91, 1999.

[37] B. R. Rajeswara Rao and M. Singh, "Effect of NPK fertilizers and spacing on periwinkle (Catharanthus roseus) under irrigated and rained conditions," Herba Hungarica, vol. 29, pp. 1-2, 1990.

[38] M. R. Shylaja, M. A. Sankar, G. S. Nair, and K. A. Mercy, "Response of Catharanthus roseus L. (G. Don) to nitrogen, phosphorus and potassium fertilization," Indian Cocoa, Arecanut and Spices Journal, vol. 20, pp. 83-88, 1996.

[39] M. R. Shylaja, A. Ashashankar, and G. S. Nair, "Effect of N, P and $\mathrm{K}$ on the leaf alkaloid content in Catharanthus roseus L. (G. Don)," Indian Journal of Horticulture, vol. 46, pp. 192-195, 1998.

[40] Y. Sreevalli, R. N. Kulkarni, K. Baskaran, and R. S. Chandrashekara, "Increasing the content of leaf and root alkaloids of high alkaloid content mutants of periwinkle through nitrogen fertilization," Industrial Crops and Products, vol. 19, no. 2, pp. 191-195, 2004.

[41] Z. Gholamhosseinpour, K. Hemati, H. Dorodian, and Z. BashirSadr, "Effect of nitrogen fertilizer on yield and amount of alkaloids in periwinkle and determination of vinblastine and vincristine by HPLC and TLC," Plant Sciences Research, vol. 3, pp. 4-9, 2011. 
[42] S. Maiti, "Inventory, documentation and status of medicinal plants research in India," in Medicinal Plants Research in Asia, Volume I: The Framework and Project Workplans, P. A. Batugal, J. Kanniah, S. Y. Lee, and J. T. Oliver, Eds., p. 89, International Genetic Resources Institute-Regional Office for Asia, the Pacific and Oceania (IPGRI-APO), Selangor, Malaysia, 2004.

[43] B. K. Jana and B. Varghese, "Effect of mineral nutrition on growth and alkaloid content of Catharanthus roseus," Indian Agriculture, vol. 40, pp. 93-99, 1996.

[44] B. N. Dahatonde, "Effect of non-monetary inputs on the yielding performance of periwinkle (Catharanthus sp.)," Ancient Science of Life, vol. 5, pp. 65-67, 1985.

[45] P. P. Khode, P. U. Ghatol, S. A. Bhuyar, D. D. Deo, and V. M. Dhumal, "Performance of Vinca rosea (Catharanthus SPP.) to different fertility and irrigation levels," Agricultural Science Digest, vol. 20, no. 2, pp. 135-136, 2000.

[46] Z. Staszewski, Z. Bodzon, and B. Lata, "Possibilities and limitations of seed production of Catharanthus roseus (L.) G. Don under Polish climatic conditions," Phytochemistry Reviews, vol. 6, no. 2-3, pp. 397-402, 2007.

[47] P. A. Thomas, J. Woodward, F. E. Stegelin, and S. V. Pennisi, A Guide for Commercial Production of Vinca. Bulletin 1219, 2009.

[48] R. N. Kulkarni, K. Bhaskaran, R. S. Chandrashekhara et al., "Dhawal-a high alkaloid producing periwinkle plant," USA Patent 6548746.

[49] S. Kumar, S. P. Rai, S. K. Rai, D. V. Singh, S. Srivastava, and R. K. Mishra, "Plant variety of Catharanthus roseus named 'lli," United States Patent PP18315, 2007.

[50] G. H. Schmelzer and A. Gurib-Fakim, Plant Resources of Tropical Africa: Medicinal Plants, PROTA Foundation, Backhuys, CTA, Wageningen, The Netherlands, 2008.

[51] T. K. Howe and W. E. Waters, "Evaluation of Catharanthus roseus (Vinca) cultivars for the landscape," in Proceedings of the Florida State Horticultural Society, vol. 107, pp. 404-408, 1994.

[52] W. Snoeijer, "Catharanthus roseus, the Madagascar Periwinkle, a review of its cultivars," Agricultural University Wageningen Papers, vol. 96, pp. 47-120, 1996.

[53] W. Snoeijer, International Register of Catharanthus roseus, Leiden/Amsterdam Centre for Drug Research, Division of Pharmacognosy, Leiden, The Netherlands, 2001.

[54] "USDA, ARS, National Genetic Resources Program. Germplasm Resources Information Network-(GRIN)," National Germplasm Resources Laboratory, Beltsville, Md, USA, http:// www.ars-grin.gov/cgi-bin/npgs/acc/display.pl?1548027.

[55] USDA, ARS, and National Genetic Resources Program, "Germplasm resources information network-(GRIN)," Online Database, National Germplasm Resources Laboratory, Beltsville, Md, USA, 2012, http://www.ars-grin.gov/cgi-bin/npgs/acc/display.pl?1157360.

[56] USDA and ARS, National Genetic Resources Program. Germplasm Resources Information Network-(GRIN). [Online Database], National Germplasm Resources Laboratory, Beltsville, Md, USA, 2012, http://www.ars-grin.gov/cgi-bin/npgs/acc/display.pl?1161274.

[57] USDA, ARS, and National Genetic Resources Program, Germplasm Resources Information Network-(GRIN), National Germplasm Resources Laboratory, Beltsville, Md, USA, May 2012, http://www.ars-grin.gov/cgi-bin/npgs/acc/display. pl?1573079.

[58] M. A. Bhutkar and S. B. Bhise, "Comparative studies on antioxidant properties of Catharanthus rosea and Catharanthus alba,"
International Journal of PharmTech Research, vol. 3, no. 3, pp. 1551-1556, 2011.

[59] M. Idrees, M. Naeem, and M. M. A. Khan, "The superiority of cV "rosea" over cv "alba" of periwinkle (Catharanthus roseus L.) in alkaloid production and other physiological attributes," Turkish Journal of Biology, vol. 34, no. 1, pp. 81-88, 2010.

[60] S. Kumar, S. Chaudhary, R. Kumari, V. Sharma, and A. Kumar, "Development of improved horticultural genotypes characterized by novel over-flowering inflorescence trait in periwinkle Catharanthus roseus," Proceedings of the National Academy of Sciences India Section B: Biological Sciences, vol. 82, no. 3, pp. 399-404, 2012.

[61] C. A. Jaleel, R. Gopi, G. M. Alagu Lakshmanan, and R. Panneerselvam, "Triadimefon induced changes in the antioxidant metabolism and ajmalicine production in Catharanthus roseus (L.) G. Don," Plant Science, vol. 171, no. 2, pp. 271-276, 2006.

[62] H. A. Curry, "Naturalising the exotic and exoticising the naturalised: horticulture, natural history and the rosy periwinkle," Environment and History, vol. 18, no. 3, pp. 343-365, 2012.

[63] I.-M. Lee, D. E. Gundersen-Rindal, and A. Bertaccini, "Phytoplasma: ecology and genomic diversity," Phytopathology, vol. 88, no. 12, pp. 1359-1366, 1998.

[64] S. Jagoueix-Eveillard, F. Tarendeau, K. Guolter, J.-L. Danet, J. M. Bové, and M. Garnier, "Catharanthus roseus genes regulated differentially by mollicute infections," Molecular Plant-Microbe Interactions, vol. 14, no. 2, pp. 225-233, 2001.

[65] F. D. Andreote, P. T. Lacava, C. S. Gai et al., "Model plants for studying the interaction between Methylobacterium mesophilicum and Xylella fastidiosa," Canadian Journal of Microbiology, vol. 52, no. 5, pp. 419-426, 2006.

[66] L. Torres, E. Galdeano, D. Docampo, and L. Conci, "Characterization of aster yellows phytoplasma associated with Catharanthus little leaf in Argentina," Journal of Plant Pathology, vol. 86, no. 3, pp. 209-214, 2004.

[67] O. F. Omar, A. A. Emeran, and J. M. Abass, "Detection of phytoplasma associated with periwinkle virescence in Egypt," Plant Pathology Journal, vol. 7, no. 1, pp. 92-97, 2008.

[68] Y. Chaturvedi, A. K. Tewari, P. P. Upadhyaya, S. K. Prabhuji, and G. P. Rao, "Association of Candidatus phytoplasma asteris with little leaf and phyllody disease of Catharanthus roseus in Eastern Uttar Pradesh, India," International Journal of Phytomedicines and Related Industries, vol. 1, pp. 103-108, 2009.

[69] Khew KL, R. E. Davis, C. A. Ong, I.-M. Lee, H. J. Su, and M. C. Tsai, "Detection of a Malaysian mycoplasmalike organism (MLO) and its differentiation from other Asian, European, and North American MLOs by use of cloned chromosomal and extra chromosomal MLO DNA probes," Journal of Plant Protection in the Tropics, vol. 8, pp. 167-180, 1991.

[70] N. Nejat, K. Sijam, S. N. A. Abdullah, G. Vadamalai, and M. Dickinson, "Molecular characterization of an aster yellows phytoplasma associated with proliferation of periwinkle in Malaysia," African Journal of Biotechnology, vol. 9, no. 15, pp. 2305-2315, 2010.

[71] N. K. K. Win and H.-Y. Jung, "The distribution of phytoplasmas in myanmar," Journal of Phytopathology, vol. 160, no. 3, pp. 139145, 2012.

[72] I.-M. Lee, D. E. Gundersen-Rindal, R. E. Davis, and I. M. Bartoszyk, "Revised classification scheme of phytoplasmas based on RFLP analyses of $16 \mathrm{~S}$ rRNA and ribosomal protein gene sequences," International Journal of Systematic Bacteriology, vol. 48, no. 4, pp. 1153-1169, 1998. 
[73] D. E. Gundersen, I.-M. Lee, S. A. Rehner, R. E. Davis, and D. T. Kingsbury, "Phylogeny of mycoplasmalike organisms (phytoplasmas): a basis for their classification," Journal of Bacteriology, vol. 176, no. 17, pp. 5244-5254, 1994.

[74] N. Nejat, K. Sijam, S. N. A. Abdullah, G. Vadamalai, and M. Dickinson, "Phytoplasmas associated with disease of coconut in Malaysia: phylogenetic groups and host plant species," Plant Pathology, vol. 58, no. 6, pp. 1152-1160, 2009.

[75] N. Nejat, G. Vadamalai, and R. E. Davis, “Candidatus Phytoplasma malaysianum, a novel taxon associated with virescence and phyllody of Madagascar periwinkle (Catharanthus roseus)," International Journal of Systematic and Evolutionary Microbiology, vol. 63, no. 2, pp. 540-548, 2013.

[76] R. M. Allen, "Spiroplasma organism found in naturally infected periwinkle," Citrograph, vol. 60, pp. 428-446, 1975.

[77] J. M. Bové, "Stubborn and its natural transmission in the Mediterranean area and the Near East," FAO Plant Protection Bulletin, vol. 34, pp. 15-23, 1986.

[78] N. Nejat, G. Vadamalai, K. Sijam, and M. Dickinson, "First report of Spiroplasma citri (-induced) associated with periwinkle lethal yellows in Southeast Asia," Plant Disease, vol. 95, no. 10, p. 1312, 2011.

[79] D. D. Shukla, D. S. Teakle, and K. H. Gough, "Periwinkle, a latent host for broad bean wilt and cucumber mosaic viruses in Australia," Plant Disease, vol. 64, pp. 802-803, 1980.

[80] A. Samad, P. V. Ajayakumar, M. K. Gupta et al., "Natural infection of periwinkle (Catharanthus roseus) with Cucumber mosaic virus, subgroup IB," Australasian Plant Disease Notes, vol. 3, pp. 30-34, 2008.

[81] M. Mazidah, K. Yusoff, H. Habibuddin, Y. H. Tan, and W. H. Lau, "Characterization of cucumber mosaic virus (CMV) causing mosaic symptom on Catharanthus roseus (L.) G. Don in Malaysia," Pertanika Journal of Tropical Agricultural Science, vol. 35, no. 1, pp. 41-53, 2012.

[82] J. F. Dastur, "Phytophthora on Vinca rosea," in Memoirs of the Department of Agriculture in India, vol. 8 of Botanical Series, pp. 233-242, 1916.

[83] A. R. Chase, "Phytophthora aerial blight of vinca and other bedding plants," Western Connection Turf \& Ornamentals, vol. 1, pp. 1-4, 1999.

[84] R. Keim, "Foliage blight of perwinkle in southern California," Plant Disease Report, vol. 61, pp. 182-184, 1977.

[85] R. T. McMillan Jr. and J. F. Garofalo, "Phytophthora parasitica wilt of new cultivars of Catharanthus roseus," Proceedings of the Florida State Horticultural Society, vol. 117, pp. 316-317, 2004.

[86] W. C. Chung, J. W. Huang, and J. C. Sheu, "Fusarium root rot of periwinkle in Taiwan," Plant Protection Bulletin, vol. 40, pp. 177-183, 1998.

[87] R. J. McGovern, T. E. Seijo, and T. A. Davis, "Evaluation of fungicides and a fertilizer for control of Phytophthora blight in Madagascar periwinkle," Fungic Nematicide Tests, vol. 58, p. OT048, 2003.

[88] R. T. McMillan Jr. and W. R. Graves, "Periwinkle twig blight caused by Colletotricum dematium on Catharanthus roseus L," Proceedings of the Florida State Horticultural Society, vol. 9, no. 109, pp. 19-20, 1996.

[89] W. Hao, P. A. Richardson, and C. X. Hong, "Foliar blight of annual vinca (Catharanthus roseus) caused by Phytophthora tropicalis in Virginia," Plant Disease, vol. 94, no. 2, article 274, 2010.
[90] M. L. Daughtrey, R. L. Wick, and J. L. Peterson, Compendium of Flowering Potted Plant Diseases, APS Press, St Paul, Minn, USA, 1995.

[91] A. Garibaldi, D. Bertetti, and M. L. Gullino, "First report of botrytis blight caused by Botrytis cinerea on Periwinkle (Catharanthus roseus) in Italy," Plant Disease, vol. 93, no. 5, p. $554,2009$.

[92] W. Ou-Yang and W. S. Wu, "Survey of periwinkle diseases in Taiwan," Plant Pathology Bulletin, vol. 7, pp. 147-149, 1998.

[93] M. Baligh, M. A. Delgado, and K. E. Conway, "Evaluation of Burkholderia cepacia strains: root colonization of Catharanthus roseus and in-vitro inhibition of selected soil-borne fungal pathogens," Proceedings of the Oklahoma Academy of Science, vol. 79, pp. 19-27, 1999.

[94] D. M. Benson, "Aluminum amendment of potting mixes for control of phytophthora damping-off in bedding plants," HortScience, vol. 30, no. 7, pp. 1413-1416, 1995.

[95] J. R. Burns and D. M. Benson, "Biocontrol of damping-off of Catharanthus roseus caused by Pythium ultimum with Trichoderma virens and binucleate Rhizoctonia fungi," Plant Disease, vol. 84, no. 6, pp. 644-648, 2000.

[96] C. B. Yandoc, E. N. Rosskopf, D. A. Shah, and J. P. Albano, "Effect of fertilization and biopesticides on the infection of Catharanthus roseus by Phytophthora nicotianae," Plant Disease, vol. 91, no. 11, pp. 1477-1483, 2007.

[97] N. R. Mustafa and R. Verpoorte, "Phenolic compounds in Catharanthus roseus," Phytochemistry Reviews, vol. 6, no. 2-3, pp. 243-258, 2007.

[98] F. Ferreres, D. M. Pereira, P. Valentão, P. B. Andrade, R. M. Seabra, and M. Sottomayor, "New phenolic compounds and antioxidant potential of Catharanthus roseus," Journal of Agricultural and Food Chemistry, vol. 56, no. 21, pp. 9967-9974, 2008.

[99] R. Candido and D. M. Martinez, "The stability of an acid-base indicator paper from Catharanthus roseus (Periwinkle) flower extract,” WMSU Research Journal, vol. 28, no. 1, pp. 1-13, 2009.

[100] S. U. Kokil, D. G. Joshi, and R. L. Jadhav, "Catharanthus roseus flower extract as natural indicator in acid base titration," Articlesbase, 2007, http://www.articlesbase.com/science-articles/catharanthus-roseus-flower-extract-as-natural-indicatorin-acid-base-titration-236311.html.

[101] M. Daniel, Medicinal Plants: Chemistry and Properties, Science Publishers, 2006.

[102] S. Hisiger and M. Jolicoeur, "Analysis of Catharanthus roseus alkaloids by HPLC," Phytochemistry Reviews, vol. 6, no. 2-3, pp. 207-234, 2007.

[103] J.-H. Renault, J.-M. Nuzillard, G. Le Crouérour, P. Thépenier, M. Zèches-Hanrot, and L. Le Men-Olivier, "Isolation of indole alkaloids from Catharanthus roseus by centrifugal partition chromatography in the $\mathrm{pH}$-zone refining mode," Journal of Chromatography A, vol. 849, no. 2, pp. 421-431, 1999.

[104] L. Wang, Y. Zhang, H. P. He, Q. Zhang, S. F. Li, and X. J. Hao, "Three new terpenoid indole alkaloids from Catharanthus roseus," Planta Medica, vol. 77, no. 7, pp. 754-758, 2011.

[105] J. A. Duke, Handbook of Medicinal Herbs: Catharanthus roseus, CRC Press, Boca Raton, Fla, USA, 1985.

[106] O. P. Virmani, G. N. Srivastava, and P. Singh, "Catharanthus roseus the tropical periwinkle," Indian Drugs, vol. 15, pp. 231252,1978 .

[107] K. Sukumar and Z. Osmani, "Insect sterilants from Catharanthus roseus," Current Science, vol. 50, no. 12, pp. 552-553, 1981. 
[108] M. R. Narayana and B. P. Dimri, Periwinkle and its Cultivation in India, CIMAP, Lucknow, India, 1990.

[109] E. Vega-Ávila, J. L. Cano-Velasco, F. J. Alarcón-Aguilar, M. D. C. Fajardo Ortíz, J. C. Almanza-Pérez, and R. Román-Ramos, "Hypoglycemic activity of aqueous extracts from Catharanthus roseus," Evidence-Based Complementary and Alternative Medicine, vol. 2012, Article ID 934258, 7 pages, 2012.

[110] H. D. Neuwinger, African Traditional Medicine: A Dictionary of Plant Use and Applications, Medpharm Scientific, Stuttgart, Germany, 2000.

[111] J. X. Guo, T. Kimura, P. P. H. But, C. K. Sung, and B. H. Han, International Collation of Traditional and Folk Medicine, vol. 4, World Scientific Publishers, 2001.

[112] D. Levêque and F. Jehl, "Molecular pharmacokinetics of Catharanthus (Vinca) alkaloids," The Journal of Clinical Pharmacology, vol. 47, no. 5, pp. 579-588, 2007.

[113] S. Nobili, D. Lippi, E. Witort et al., "Natural compounds for cancer treatment and prevention," Pharmacological Research, vol. 59, no. 6, pp. 365-378, 2009.

[114] M. A. Jordan and L. Wilson, "Microtubules as a target for anticancer drugs," Nature Reviews Cancer, vol. 4, no. 4, pp. 253265, 2004.

[115] R. J. Sherines and S. S. Howard, "Male infertility," in Campbells Urology, J. H. Harrison, R. F. Gittes, A. D. Perlmutter, T. A. Stamey, and P. C. Walsh, Eds., vol. 1, p. 715, WB Saunders, Philadelphia, Pa, USA, 4th edition, 1978.

[116] S. A. James, L. Bilbiss, and B. Y. Muhammad, "The effects of Catharanthus roseus (L) G. Don 1838 aqueous leaf extract on some liver enzymes, serum proteins and vital organs," Science World Journal, vol. 2, pp. 5-9, 2007.

[117] J. M. Pezzuto, "Plant-derived anticancer agents," Biochemical Pharmacology, vol. 53, no. 2, pp. 121-133, 1997.

[118] V. E. Tyler, “Medicinal plant research: 1953-1987," Planta Medica, vol. 54, no. 2, pp. 95-100, 1988.

[119] R. Verpoorte, R. van der Heijden, J. Schripsema, J. H. C. Hoge, and H. J. G. Ten Hoopen, "Plant cell biotechnology for the production of alkaloids: present status and prospects," Journal of Natural Products, vol. 56, no. 2, pp. 186-207, 1993.

[120] G. H. Schmelzer, "Catharanthus roseus (L.)," in Medicinal plants/Plantes médicinales 1, G. H. Schmelzer and A. GuribFakim, Eds., PROTA, Wageningen, The Netherlands, 2007.

[121] V. Salim, F. Yu, J. Altarejos, and V. de Luca, "Virus-induced gene silencing identifies Catharanthus roseus 7-deoxyloganic acid-7hydroxylase, a step in iridoid and monoterpene indole alkaloid biosynthesis," The Plant Journal, vol. 76, no. 5, pp. 754-765, 2013.

[122] M. Debnath, C. P. Malik, and P. S. Bisen, "Micropropagation: a tool for the production of high quality plant-based medicines," Current Pharmaceutical Biotechnology, vol. 7, no. 1, pp. 33-49, 2006.

[123] S. Foster, "From herbs to medicines: the Madagascar periwinkle's impact on childhood leukemia: a serendipitous discovery for treatment," in Alternative \& Complementary Therapies: A New Bimonthly Publication for Health Care Practitioners, J. Simon, R. Cooper, and K. Hughes, Eds., pp. 347-350, 2010.

[124] M. Y. Khan, S. Aliabbas, V. Kumar, and S. Rajkumar, "Recent advances in medicinal plant biotechnology," Indian Journal of Biotechnology, vol. 8, no. 1, pp. 9-22, 2009.

[125] A. Mujib, A. Ilah, N. Gandotra, and M. Z. Abdin, "In vitro application to improve alkaloid yield in Catharanthus roseus," in Recent Progress in Medicinal Plants, Volume 4: Biotechnology and Genetic Engineering, J. N. Govil, P. A. Kumar, and V. K. Singh,
Eds., pp. 415-440, Sci Tech Publication, Houston, Tex, USA, 2002.

[126] M. Sottomayor and A. R. Barceló, “The Vinca alkaloids: from biosynthesis and accumulation in plant cells, to uptake, activity and metabolism in animal cells," Studies in Natural Products Chemistry, vol. 33, pp. 813-857, 2005.

[127] S. Binet, E. Chaineau, A. Fellous et al., "Immunofluorescence study of the action of navelbine, vincristine and vinblastine on mitotic and axonal microtubules," International Journal of Cancer, vol. 46, no. 2, pp. 262-266, 1990.

[128] C. Antonio, N. R. Mustafa, S. Osorio et al., "Analysis of the interface between primary and secondary metabolism in Catharanthus roseus cell cultures using $13 \mathrm{C}$-stable isotope feeding and coupled mass spectrometry," Molecular Plant, vol. 6, no. 2, pp. 581-584, 2013.

[129] H. Rischer, M. Orešič, T. Seppänen-Laakso et al., "Gene-tometabolite networks for terpenoid indole alkaloid biosynthesis in Catharanthus roseus cells," Proceedings of the National Academy of Sciences of the United States of America, vol. 103, no. 14, pp. 5614-5619, 2006.

[130] A. Dutta, J. Batra, S. Pandey-Rai, D. Singh, S. Kumar, and J. Sen, "Expression of terpenoid indole alkaloid biosynthetic pathway genes corresponds to accumulation of related alkaloids in Catharanthus roseus (L.) G. Don," Planta, vol. 220, no. 3, pp. 376-383, 2005.

[131] P. Mishra, G. C. Uniyal, S. Sharma, and S. Kumar, "Pattern of diversity for morphological and alkaloid yield related traits among the periwinkle Catharanthus roseus accessions collected from in and around Indian subcontinent," Genetic Resources and Crop Evolution, vol. 48, no. 3, pp. 273-286, 2001.

[132] S. P. Rai, R. Luthra, and S. Kumar, "Salt-tolerant mutants in glycophytic salinity response (GSR) genes in Catharanthus roseus," Theoretical and Applied Genetics, vol. 106, no. 2, pp. 221230, 2003.

[133] K.-M. Oksman-Caldentey and D. Inzé, "Plant cell factories in the post-genomic era: new ways to produce designer secondary metabolites," Trends in Plant Science, vol. 9, no. 9, pp. 433-440, 2004.

[134] M. El-Sayed and R. Verpoorte, "Catharanthus terpenoid indole alkaloids: biosynthesis and regulation," Phytochemistry Reviews, vol. 6, no. 2-3, pp. 277-305, 2007.

[135] P. Lackman, M. González-Guzmán, S. Tilleman et al., "Jasmonate signaling involves the abscisic acid receptor PYL4 to regulate metabolic reprogramming in Arabidopsis and tobacco," Proceedings of the National Academy of Sciences of the United States of America, vol. 108, no. 14, pp. 5891-5896, 2011.

[136] P. R. Moreno, R. Van Der Heijden, and R. Verpoorte, "Cell and tissue cultures of Catharanthus roseus: a literature survey," Plant Cell, Tissue and Organ Culture, vol. 42, no. 1, pp. 1-25, 1995.

[137] A. Datta and P. S. Srivastava, "Variation in vinblastine production by Catharanthus roseus, during in vivo and in vitro differentiation," Phytochemistry, vol. 46, no. 1, pp. 135-137, 1997.

[138] Y. Miura, K. Hirata, N. Kurano, K. Miyamoto, and K. Uchida, "Formation of vinblastine in multiple shoot culture of Catharanthus roseus," Planta Medica, vol. 54, no. 1, pp. 18-20, 1988.

[139] A. Ataei-Azimi, H. B. Delnavaz, H. Ebrahimzadeh, and A. Majd, "High in vitro production of ant-canceric indole alkaloids from periwinkle (Catharanthus roseus) tissue culture," African Journal of Biotechnology, vol. 7, no. 16, pp. 2834-2839, 2008.

[140] S. Yokoshima, T. Ueda, S. Kobayashi et al., "Stereocontrolled total synthesis of (+)-vinblastine," Journal of the American Chemical Society, vol. 124, no. 10, pp. 2137-2139, 2002. 
[141] J. Liu, J. Zhu, L. Tang, W. Wen, S. Lv, and R. Yu, "Enhancement of vindoline and vinblastine production in suspension-cultured cells of Catharanthus roseus by artemisinic acid elicitation," World Journal of Microbiology and Biotechnology, vol. 30, no. 1, pp. 175-180, 2014.

[142] M. Koul, N. S. Lakra, R. Chandra, and S. Chandra, "Catharanthus roseus and prospects of its endophytes: a new avenue for production of bioactive metabolites," International Journal of Pharmaceutical Sciences and Research, vol. 4, no. 7, pp. 27052716, 2013.

[143] R. N. Kharwar, V. C. Verma, G. Strobel, and D. Ezra, "The endophytic fungal complex of Catharanthus roseus (L.) G. Don," Current Science, vol. 95, no. 2, pp. 228-233, 2008.

[144] L. B. Zhang, L. H. Gou, and S. V. Zeng, "Preliminary study on the isolation of endophytic fungus of Catharanthus roseus and its fermentation to produce product of therapeutic value," Chinese Traditional and Herbal Drugs, vol. 11, pp. 805-807, 2000.

[145] C. Y. Tung, D. B. Yang, and M. Gou, "A preliminary study on the condition of the culture and isolate of endophytic fungus producing Vincristine," Journal of Chuxiong Normal University, vol. 6, pp. 39-41, 2002.

[146] B. Guo and L. H. Kunming, "A middle vinblastine fungi isolated," Journal of Yunnan University, vol. 20, pp. 214-215, 1998.

[147] A. Kumar, D. Patil, P. R. Rajamohanan, and A. Ahmad, "Isolation, purification and characterization of vinblastine and vincristine from endophytic fungus Fusarium oxysporum isolated from Catharanthus roseus," PLoS ONE, vol. 8, no. 9, Article ID e71805, 2013.

[148] M. M. R. Costa, F. Hilliou, P. Duarte et al., "Molecular cloning and characterization of a vacuolar class III peroxidase involved in the metabolism of anticancer alkaloids in Catharanthus roseus," Plant Physiology, vol. 146, no. 2, pp. 403-417, 2008.

[149] D. I. Jacobs, M. Gaspari, J. Van Der Greef, R. Van Der Heijden, and R. Verpoorte, "Proteome analysis of the medicinal plant Catharanthus roseus," Planta, vol. 221, no. 5, pp. 690-704, 2005.

[150] A. Champagne, H. Rischer, K. M. Oksman-Caldentey, and M. Boutry, "In-depth proteome mining of cultured Catharanthus roseus cells identifies candidate proteins involved in the synthesis and transport of secondary metabolites," Proteomics, vol. 12, no. 23-24, pp. 3536-3547, 2012.

[151] G. W. Sander, Quantitative analysis of metabolic pathways in Catharanthus roseus hairy roots metabolically engineered for terpenoid indole alkaloid overproduction [Ph.D. thesis], Iowa State University, Ames, Iowa, USA, 2009.

[152] C. Zhou, J. Zhang, S.-J. Zhao, and Z.-B. Hu, "An active Catharanthus roseus desacetoxyvindoline-4-hydroxylase-like gene and its transcriptional regulatory profile," Botanical Studies, vol. 55, no. 1, article 29, 2014.

[153] Q. Pan, Q. Wang, F. Yuan et al., "Overexpression of ORCA3 and $\mathrm{G10H}$ in Catharanthus roseus plants regulated alkaloid biosynthesis and metabolism revealed by NMR-metabolomics," PLoS ONE, vol. 7, no. 8, Article ID e43038, 2012.

[154] S. E. O'Connor and J. J. Maresh, "Chemistry and biology of monoterpene indole alkaloid biosynthesis," Natural Product Reports, vol. 23, no. 4, pp. 532-547, 2006.

[155] T. Hashimoto and Y. Yamada, "New genes in alkaloid metabolism and transport," Current Opinion in Biotechnology, vol. 14, no. 2, pp. 163-168, 2003.

[156] M. Wink and M. Roberts, "Compartmentation of alkaloid synthesis, transport, and storage," in Alkaloids, M. Roberts and M. Wink, Eds., pp. 301-307, Plenum Press, New York, NY, USA, 1998.
[157] O. Ginis, V. Courdavault, C. Melin et al., "Molecular cloning and functional characterization of Catharanthus roseus hydroxymethylbutenyl 4-diphosphate synthase gene promoter from the methyl erythritol phosphate pathway," Molecular Biology Reports, vol. 39, no. 5, pp. 5433-5447, 2012.

[158] Y.-C. Sung, C.-P. Lin, and J.-C. Chen, "Optimization of virusinduced gene silencing in Catharanthus roseus," Plant Pathology, vol. 63, no. 5, pp. 1159-1167, 2014.

[159] S. W. Kim, S. H. Ban, S.-C. Jeong et al., "Genetic discrimination between Catharanthus roseus cultivars by metabolic fingerprinting using ${ }^{1} \mathrm{H}$ NMR spectra of aromatic compounds," Biotechnology and Bioprocess Engineering, vol. 12, no. 6, pp. 646652, 2007.

[160] S. W. Kim, J. H. Kim, and J. R. Liu, "Genetic discrimination of Catharanthus roseus cultivars by pyrolysis mass spectrometry," Journal of Plant Biology, vol. 52, no. 5, pp. 462-465, 2009.

[161] R. K. Shaw, L. Acharya, and A. K. Mukherjee, "Assessment of genetic diversity in a highly valuable medicinal plant Catharanthus roseus using molecular markers," Crop Breeding and Applied Biotechnology, vol. 9, no. 1, pp. 52-59, 2009.

[162] M. Magnotta, J. Murata, J. Chen, and V. de Luca, "Identification of a low vindoline accumulating cultivar of Catharanthus roseus (L.) G. Don by alkaloid and enzymatic profiling," Phytochemistry, vol. 67, no. 16, pp. 1758-1764, 2006.

[163] Y. D. Qing, P. BinYe, R. D. L. Kun et al., "ISSR analysis of genetic relationships between forty varieties of Catharanthus roseus," Journal of Shanghai Jiaotong University-Agricultural Science, vol. 27, pp. 138-142, 2011.

[164] S. Lal, K. N. Mistry, S. D. Shah, R. Thaker, and P. B. Vaidya, "Genetic diversity assessment in nine cultivars of Catharanthus roseus from Central Gujarat (India) through RAPD, ISSR and SSR markers," Journal of Biological Research, vol. 8, pp. 667-675, 2011.

[165] B. Shokeen, N. K. Sethy, S. Kumar, and S. Bhatia, "Isolation and characterization of microsatellite markers for analysis of molecular variation in the medicinal plant Madagascar periwinkle (Catharanthus roseus (L.) G. Don)," Plant Science, vol. 172, no. 3, pp. 441-451, 2007.

[166] D. M. Pereira, F. Ferreres, J. Oliveira, P. Valentão, P. B. Andrade, and M. Sottomayor, "Targeted metabolite analysis of Catharanthus roseus and its biological potential," Food and Chemical Toxicology, vol. 47, no. 6, pp. 1349-1354, 2009.

[167] D. M. Pereira, F. Ferreres, J. M. A. Oliveira et al., "Pharmacological effects of Catharanthus roseus root alkaloids in acetylcholinesterase inhibition and cholinergic neurotransmission," Phytomedicine, vol. 17, no. 8-9, pp. 646-652, 2010.

[168] N. Singh, B. R. Pandey, and P. Verma, "An overview of phytotherapeutic approach in prevention and treatment of Alzheimer's Syndrome \& Dementia," International Journal of Pharmaceutical Sciences and Drug Research, vol. 3, no. 3, pp. 162-172, 2011.

[169] S. Agarwal, S. Jacob, N. Chettri et al., "Evaluation of invitro anthelminthic activity of Catharanthus roseus extract," The International Journal of Pharmaceutical Sciences and Drug Research, vol. 3, no. 3, pp. 211-213, 2011.

[170] T. Murugavel and M. A. Akbarsha, "Anti-spermatogenic effect of Vinca rosea Linn," Indian Journal of Experimental Biology, vol. 29, no. 9, pp. 810-812, 1991.

[171] S. Wang, Z. Zheng, Y. Weng et al., "Angiogenesis and antiangiogenesis activity of Chinese medicinal herbal extracts," Life Sciences, vol. 74, no. 20, pp. 2467-2478, 2004. 
[172] P. Goyal, A. Khanna, A. Chauhan, G. Chauhan, and P. Kaushik, "In vitro evaluation of crude extracts of Catharanthus roseus for potential antibacterial activity," International Journal of Green Pharmacy, vol. 2, pp. 176-181, 2008.

[173] P. J. Patil and J. S. Ghosh, "Antimicrobial activity of Catharanthus roseus-a detailed study," British Journal of Pharmacology and Toxicology, vol. 1, pp. 40-44, 2010.

[174] S. Ramya, V. Govindaraji, K. Navaneetha, and R. Jayakumararaj, "In vitro evaluation of antibacterial activity using crude extracts of Catharanthus roseus L. (G.) Don," Ethnobotanical Leaflets, vol. 12, pp. 1067-1072, 2008.

[175] A. K. Verma and R. R. Singh, "Induced dwarf mutant in Catharanthus roseus with enhanced antibacterial activity," Indian Journal of Pharmaceutical Sciences, vol. 72, no. 5, pp. 655-657, 2010.

[176] K. A. Hassan, A. T. Brenda, V. Patrick, and O. E. Patrick, "In vivo antidiarrheal activity of the ethanolic leaf extract of Catharanthus roseus linn. (Apocyanaceae) in wistar rats," African Journal of Pharmacy and Pharmacology, vol. 5, no. 15, pp. 1797-1800, 2011.

[177] R. Mathur and S. Chaudan, "Antifertility efficacy of Catharanthus roseus Linn: a biochemical and histological study," Acta Europaea Fertilitatis, vol. 16, no. 3, pp. 203-205, 1985.

[178] V. Prajapati, A. K. Tripathi, D. C. Jain, S. Sharma, and S. P. S. Khanuja, "Sensitivity of Spilarctia obliqua to root extracts of Catharanthus roseus," Phytotherapy Research, vol. 12, no. 4, pp. 270-274, 1998.

[179] S. K. Chile and K. M. Vyas, "Efficacy of Vinca rosea extracts against protease from human pathogenic strains of Trichophyton rubrum Sab," Hindustan Antibiotics Bulletin, vol. 26, no. 3-4, pp. 114-116, 1984.

[180] A. K. Barde and S. M. Singh, "Activity of plant extracts against Scytalidium anamorph of Hendersonula toruloidea causing skin and nail diseases in man," Indian Drugs, vol. 20, pp. 362-364, 1983.

[181] B. D. Benjamin, S. M. Kelkar, M. S. Pote, G. S. Kaklij, A. T. Sipahimalani, and M. R. Heble, "Catharanthus roseus cell cultures: growth, alkaloid synthesis and antidiabetic activity," Phytotherapy Research, vol. 8, no. 3, pp. 185-186, 1994.

[182] M. Bnouham, A. Ziyyat, H. Mekhfi, A. Tahri, and A. Legssyer, "Medicinal plants with potential antidiabetic activity-a review of ten years of herbal medicine research (1990-2000)," International Journal of Diabetes and Metabolism, vol. 14, no. 1, pp. 1-25, 2006.

[183] R. R. Chattopadhyay, "A comparative evaluation of some blood sugar lowering agents of plant origin," Journal of Ethnopharmacology, vol. 67, no. 3, pp. 367-372, 1999.

[184] K. Chauhan, S. Sharma, K. Rohatgi, and B. Chauhan, "Antihyperlipidemic and antioxidative efficacy of Catharanthus roseus Linn [Sadabahar] in streptozotocin induced diabetic rats," Asian Journal of Pharmaceutical and Health Sciences, vol. 2, no. 1, pp. 235-243, 2011.

[185] E. E. J. Iweala and C. U. Okeke, "Comparative study of the hypoglycemic and biochemical effects of Catharanthus roseus (Linn) G. Apocynaceae (Madagascar periwinkle) and chlorpropamide (diabenese) on alloxan-induced diabetic rats," Biokemistri, vol. 17, no. 2, pp. 149-156, 2005.

[186] E. Jarald, S. B. Joshi, and D. C. Jain, "Diabetes and herbal medicines," Iranian Journal of Pharmacology and Therapeutics, vol. 7, no. 1, pp. 97-106, 2008.

[187] S. Nammi, M. K. Boini, S. D. Lodagala, and R. B. S. Behara, "The juice of fresh leaves of Catharanthus roseus Linn. reduces blood glucose in normal and alloxan diabetic rabbits," $B M C$ Complementary and Alternative Medicine, vol. 3, no. 1, article 4, 2003.

[188] S. N. Singh, P. Vats, S. Suri et al., "Effect of an antidiabetic extract of Catharanthus roseus on enzymic activities in streptozotocin induced diabetic rats," Journal of Ethnopharmacology, vol. 76, no. 3, pp. 269-277, 2001.

[189] R. R. Chattopadhyay, R. N. Banerjee, S. K. Sarkar, S. Ganguly, and T. K. Basu, "Antiinflammatory and acute toxicity studies with the leaves of Vinca rosea linn. in experimental animals," Indian Journal of Physiology and Pharmacology, vol. 36, no. 4, pp. 291-292, 1992.

[190] C. Y. Lim-Sylianco and F. Blanco, "Antimutagenic effects of some anti-cancer agents," Bulletin of the Philippine Society for Biochemistry and Molecular Biology, vol. 4, pp. 1-7, 1981.

[191] G. M. Cragg and D. J. Newman, "Plants as a source of anticancer agents," Journal of Ethnopharmacology, vol. 100, no. 1-2, pp. 72-79, 2005.

[192] J.-G. Dong, W. Bornmann, K. Nakanishi, and N. Berova, "Structural studies of vinblastine alkaloids by exciton coupled circular dichroism," Phytochemistry, vol. 40, no. 6, pp. 1821-1824, 1995.

[193] M. M. El-Merzabani, A. A. El-Aaser, M. A. Attia, A. K. ElDuweini, and A. M. Ghazal, "Screening system for Egyptian plants with potential anti-tumour activity," Planta Medica, vol. 36, no. 2, pp. 150-155, 1979.

[194] A. El-Sayed and G. A. Cordell, "Catharanthus alkaloids. XXXIV. Catharanthamine, a new antitumor bisindole alkaloid from Catharanthus roseus," Journal of Natural Products, vol. 44, no. 3, pp. 289-293, 1981.

[195] A. El-Sayed, G. A. Handy, and G. A. Cordell, "Catharanthus alkaloids, XXXVIII. Confirming structural evidence and antineoplastic activity of the bisindole alkaloids Leurosine- $\mathrm{N}_{b}^{\prime}$ oxide (pleurosine), roseadine and vindolicine from Catharanthus roseus," Journal of Natural Products, vol. 46, no. 4, pp. 517527, 1983.

[196] I. S. Johnson, H. F. Wright, G. H. Svoboda, and J. Vlantis, "Antitumor principles derived from Vinca rosea Linn. I. Vincaleukoblastine and leurosine," Cancer Research, vol. 20, pp. 1016-1022, 1960.

[197] A. K. Mukherjee, S. Basu, N. Sarkar, and A. C. Ghosh, "Advances in cancer therapy with plant based natural products," Current Medicinal Chemistry, vol. 8, no. 12, pp. 1467-1486, 2001.

[198] R. L. Noble, "The discovery of the vinca alkaloids-chemotherapeutic agents against cancer," Biochemistry and Cell Biology, vol. 68, no. 12, pp. 1344-1351, 1990.

[199] W. Zheng and S. Y. Wang, "Antioxidant activity and phenolic compounds in selected herbs," Journal of Agricultural and Food Chemistry, vol. 49, no. 11, pp. 5165-5170, 2001.

[200] J. W. Gathirwa, G. M. Rukunga, E. N. M. Njagi et al., "In vitro anti-plasmodial and in vivo anti-malarial activity of some plants traditionally used for the treatment of malaria by the Meru community in Kenya," Journal of Natural Medicines, vol. 61, no. 3, pp. 261-268, 2007.

[201] S. Ponarulselvam, C. Panneerselvam, K. Murugan, N. Aarthi, K. Kalimuthu, and S. Thangamani, "Synthesis of silver nanoparticles using leaves of Catharanthus roseus Linn. G. Don and their antiplasmodial activities," Asian Pacific Journal of Tropical Biomedicine, vol. 2, no. 7, pp. 574-580, 2012.

[202] D. R. A. Mans, A. B. da Rocha, and G. Schwartsmann, "Anticancer drug discovery and development in Brazil: targeted plant collection as a rational strategy to acquire candidate anti-cancer compounds," Oncologist, vol. 5, no. 3, pp. 185-198, 2000. 
[203] J. Y. Ueda, Y. Tezuka, A. H. Banskota et al., "Antiproliferative activity of Vietnamese medicinal plants," Biological and Pharmaceutical Bulletin, vol. 25, no. 6, pp. 753-760, 2002.

[204] R. S. Gupta and R. Sharma, "A review on medicinal plants exhibiting antifertility activity in males," Natural Product Radiance, vol. 5, pp. 389-410, 2006.

[205] M. S. Joshi and R. Y. Ambaye, "Effect of alkaloids from Vinca rosea L. on spermatogenesis in male rats," Indian Journal of Experimental Biology, vol. 6, no. 4, pp. 256-257, 1968.

[206] D. E. Moerman, Native American Medicinal Plants: An Ethnobotanical Dictionary, Timber Press, Portland, Ore, USA, 2009.

[207] T. Usia, T. Watabe, S. Kadota, and Y. Tezuka, "Cytochrome P450 2D6 (CYP2D6) inhibitory constituents of Catharanthus roseus," Biological and Pharmaceutical Bulletin, vol. 28, no. 6, pp. 10211024, 2005.

[208] K. Hostettmann, A. Marston, K. Ndjoko, and J.-L. Wolfender, "The potential of African plants as a source of drugs," Current Organic Chemistry, vol. 4, no. 10, pp. 973-1010, 2000.

[209] M. J. Siddiqui, Z. Ismail, A. F. A. Aisha, and A. M. S. Abdul Majid, "Cytotoxic activity of Catharanthus roseus (Apocynaceae) crude extracts and pure compounds against human colorectal carcinoma cell line," International Journal of Pharmacology, vol. 6, no. 1, pp. 43-47, 2010.

[210] D. A. Adekomi, "Madagascar periwinkle (Catharanthus roseus) enhances kidney and liver functions in Wistar rats," European Journal of Anatomy, vol. 14, no. 3, pp. 111-119, 2010.

[211] H. I. Averal, A. Stanley, P. Murugaian, M. Palanisamy, and M. A. Akbarsha, "Specific effect of vincristine on epididymis," Indian Journal of Experimental Biology, vol. 34, no. 1, pp. 53-56, 1996.

[212] A. Stanley and M. A. Akbarsha, "Giant spermatogonial cells generated by vincristine and their uses," Current Science, vol. 63, no. 3, pp. 144-147, 1992.

[213] C. Kuppusamy, K. Murugan, N. Arul, and P. Yasodha, "Larvici$\mathrm{dal}$ and insect growth regulator effect of $\alpha$-amyrin acetate from Catharanthus roseus Linn against the malaria vector Anopheles stephensi Liston (Diptera: Culicidae)," Entomological Research, vol. 39, no. 1, pp. 78-83, 2009.

[214] K. M. Remia and S. Logaswamy, "Larvicidal efficacy of leaf extract of two botanicals against the mosquito vector Aedes aegypti (Diptera: Culicidae)," Indian Journal of Natural Products and Resources, vol. 1, no. 2, pp. 208-212, 2010.

[215] M. A. Akbarsha, A. Stanley, and H. I. Averal, "Effect of vincristine on Leydig cell and accessory reproductive organs," Current Science, vol. 68, no. 10, pp. 1053-1057, 1995.

[216] A. Stanley, H. A. Averal, and M. A. Akbarsha, "Reproductive toxicity of vincristine in male rats," Indian Journal of Experimental Biology, vol. 31, no. 4, pp. 380-382, 1993.

[217] A. Kurian and A. Sankar, Medicinal Plants: Horticulture Science Series-2, New India Publishing Agency, 2007.

[218] B. S. Nayak and L. M. Pinto Pereira, "Catharanthus roseus flower extract has wound-healing activity in Sprague Dawley rats," BMC Complementary and Alternative Medicine, vol. 6, article 41, 2006. 

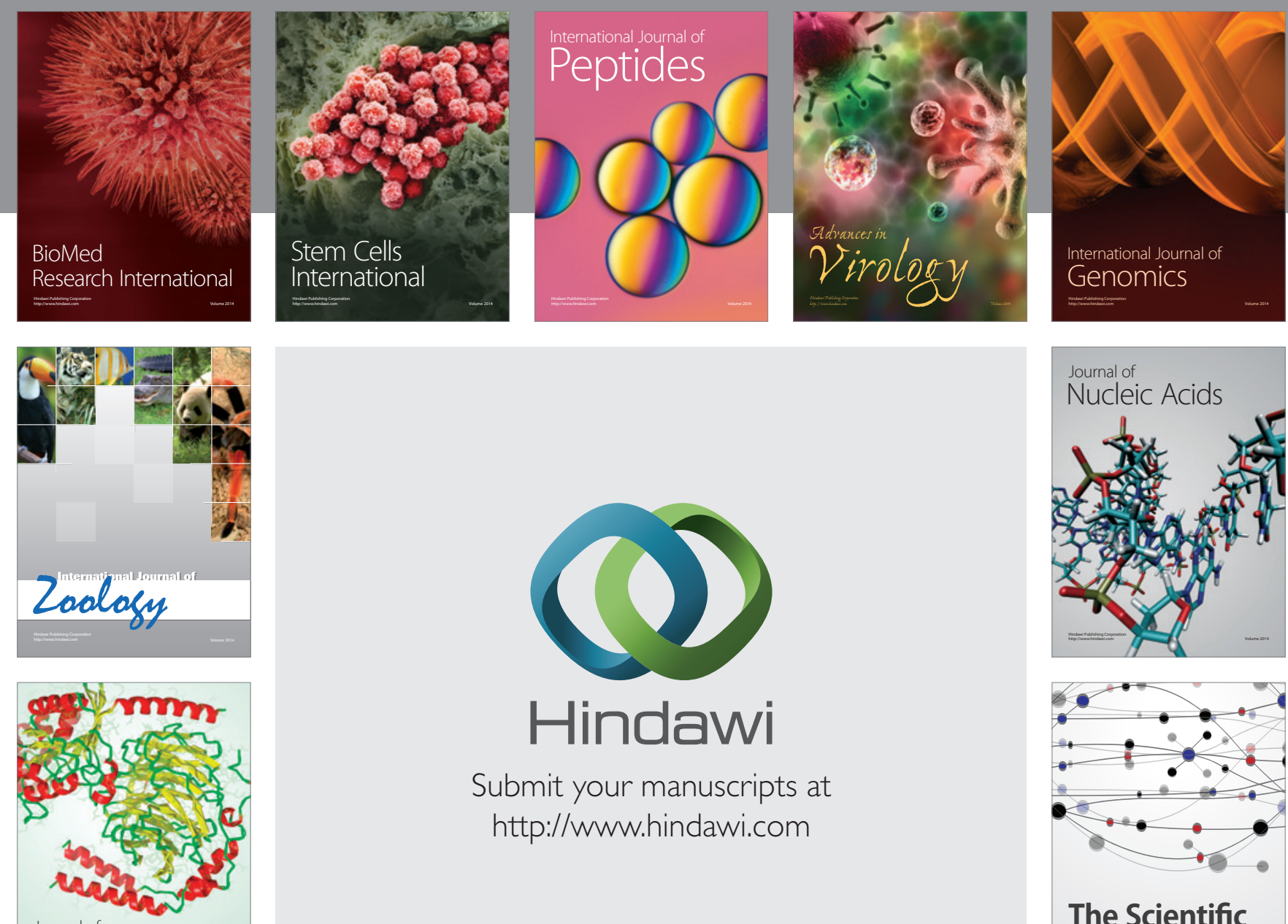

Submit your manuscripts at

http://www.hindawi.com

Journal of
Signal Transduction
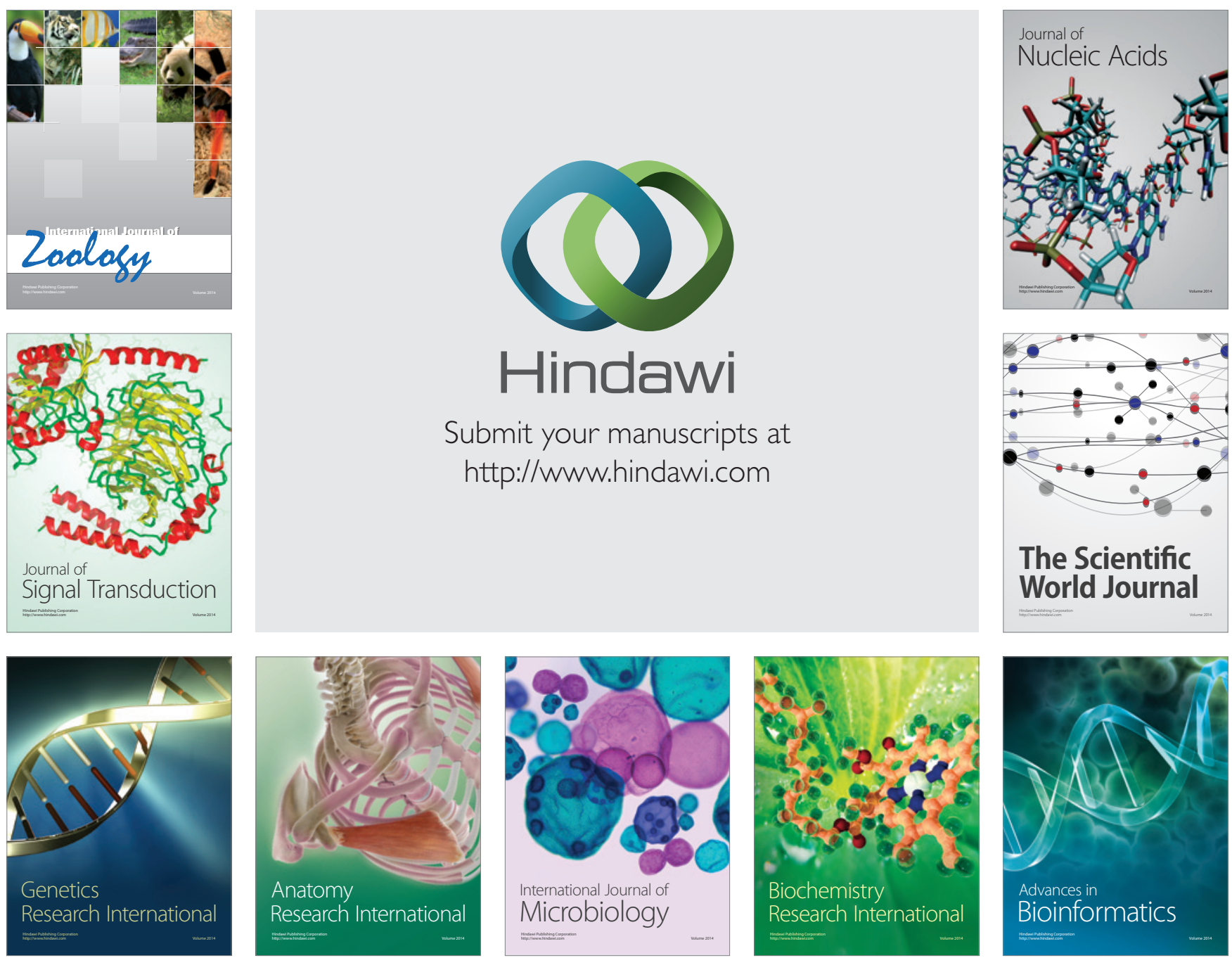

The Scientific World Journal
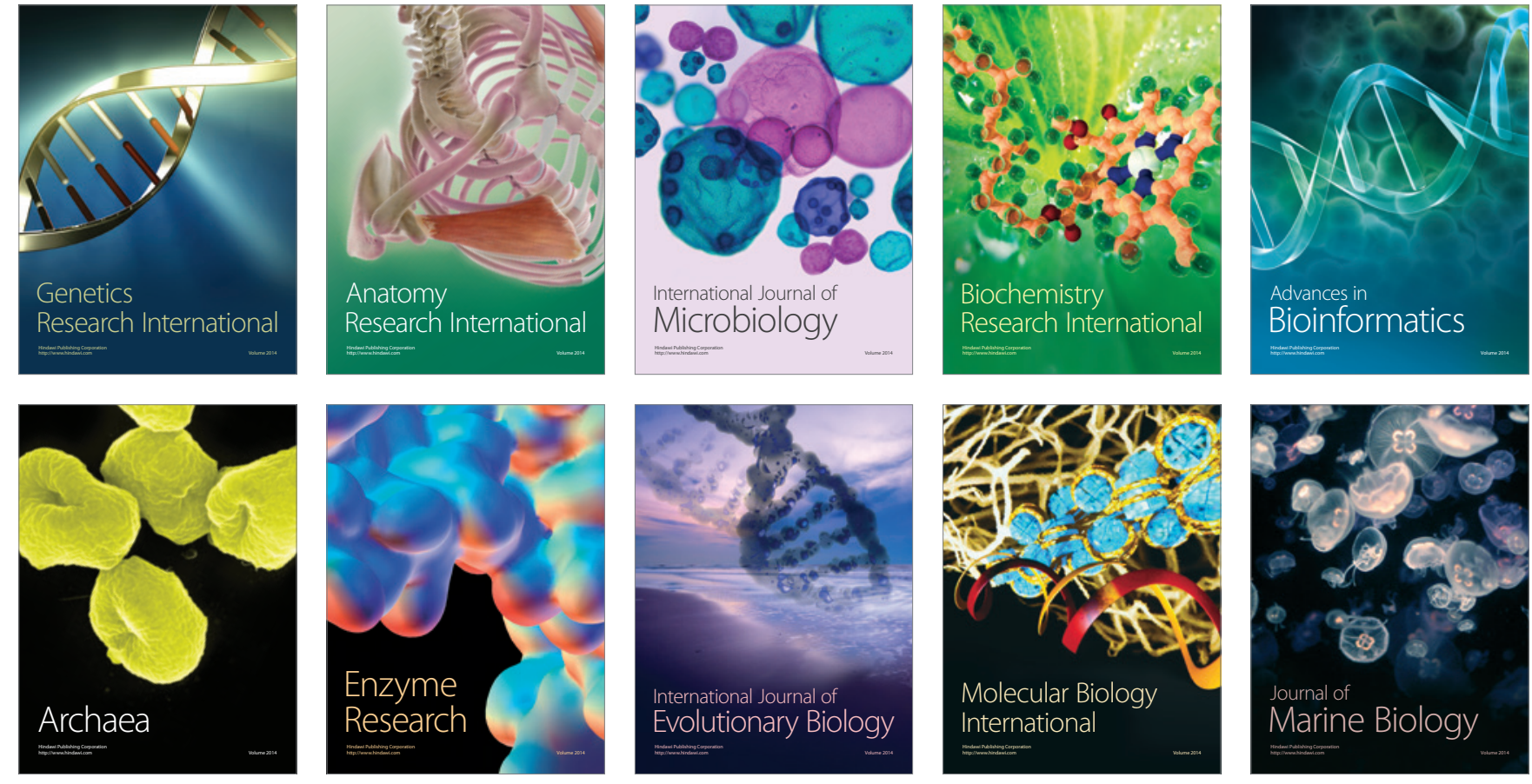